\title{
Study on the impacts of chemical and green synthesized (Leucas aspera and oxy-cyclodextrin complex) dietary zinc oxide nanoparticles in Nile tilapia (Oreochromis niloticus)
}

\author{
Amitha Kurian ${ }^{1} \cdot$ Preetham Elumalai $^{1}$ (D) \\ Received: 17 April 2020 / Accepted: 7 December 2020 / Published online: 6 January 2021 \\ (C) The Author(s) 2021
}

\begin{abstract}
The present study was designed to evaluate the health effects of dietary nanozinc prepared by two methods: conventional chemical method and green method. The parameters evaluated were the extent of bioaccumulation, antioxidant status, histological, immunological changes and DNA damage in Nile tilapia fed nanozinc feed. Zinc oxide nanoparticles were first prepared by green and chemical methods. Before feed preparation, the in vitro antioxidant activity and antibacterial activity of both types of nanoparticle solutions were tested and the results revealed enhanced activities in green synthesized $\mathrm{ZnO}$ NP solution. After the acclimatization period, 420 Nile tilapias were distributed randomly into 21 glass tanks with 20 fish per tank in triplicates. Fish were fed control diet without any ZnO NP and (i) GT1-green synthesized ZnO NP diet at $100 \mathrm{mg} / \mathrm{kg}$, (ii) CT1 — chemically synthesized ZnO NP diet at $100 \mathrm{mg} / \mathrm{kg}$, (iii) GT2 — green synthesized ZnO NP diet at $200 \mathrm{mg} / \mathrm{kg}$, (iv) CT2 — chemically synthesized ZnO NP diet at $200 \mathrm{mg} / \mathrm{kg}$, (v) GT3 — green synthesized ZnO NP diet at 400 $\mathrm{mg} / \mathrm{kg}$ and (vi) CT3 - chemically synthesized ZnO NP diet at $400 \mathrm{mg} / \mathrm{kg}$ for 60 days. After 60 days, gill and liver samples were collected for analysing oxidative stress, histopathological alterations and bioaccumulation of zinc, whereas serum samples were collected for evaluating immune response. The results revealed that the GT3 diet significantly $(P<0.05)$ enhanced the level of antioxidant enzymes (CAT, SOD, GPx, GR and GSH) than dietary nanozinc prepared by the chemical method. Similarly, the innate immunological parameters were significantly $(P<0.05)$ augmented in fish fed GT3 diet. Comparative histological study of liver and gill tissues revealed normal architecture in the tissues of fish fed green synthesized NP-enriched feed, whereas the tissues of fish fed chemically synthesized NP feed exhibited histological alterations. Bioaccumulation of zinc was more in the liver followed by the muscle and least in the gills and DNA damage was more evident in fish fed chemically synthesized $\mathrm{ZnO} \mathrm{NP}$-enriched feed. In conclusion, the results suggest that the inclusion of $400 \mathrm{mg} / \mathrm{kg}$ GT3 diet in fish diet enhanced the level of antioxidant enzymes, boosted immune response and did not cause histological damage to organs, and therefore, GT3 nanofeed can be recommended for fish health improvement.
\end{abstract}

Keywords $\mathrm{ZnO}$ nanoparticle $\cdot$ Green synthesis $\cdot$ Chemical synthesis $\cdot$ Toxicity $\cdot$ Histology $\cdot$ Immunity $\cdot$ Bioaccumulation

\section{Highlights}

- Green synthesized ZnO NP revealed greater in vitro antioxidant activity as well as antibacterial activity

- Enhancement of immune response observed more in fish fed green synthesized $\mathrm{ZnO} \mathrm{NP}$ added feed

- Enzymatic antioxidant enzyme levels significantly increased in fish fed green synthesized $\mathrm{ZnO} \mathrm{NP}$ added feed

- Histological alterations observed in fish fed chemically synthesized $\mathrm{ZnO}$ NP feed

- Oxidative DNA (8-hydroxy-2-deoxyguanosine (8-OHdG)) damage was more in fish fed chemically synthesized $\mathrm{ZnO} \mathrm{NP}-$-enriched feed

Responsible Editor: Philippe Garrigues

Preetham Elumalai

preetham@kufos.ac.in

1 School of Ocean Science and Technology, Kerala University of Fisheries and Ocean Studies, Panangad, Kochi, Kerala 682 506, India

\section{Introduction}

Nanotechnology offers incredible applications in almost all spheres of life due to which this branch of science has gained popularity and attention swiftly (Bhattacharya and Mukherjee 2008). Wide application of nanoparticles can induce serious threats to the environment which is why it is important to study the hazards of nanoparticles on the aquatic system (Kumar et al. 2010). One such widely used nanoparticle is zinc oxide. Zinc oxide nanoparticles ( $\mathrm{ZnO} \mathrm{NPs}$ ) are commercially utilized (Amornpitoksuk et al. 2011). They have promising health potential like antioxidant (Das et al. 2013), antimicrobial (Premanathan et al. 2011) and anticancer (Li et al. 2010) activities. Plant-mediated synthesis of nanoparticles, also known as green synthesis, is an eco-friendly approach 
that has reduced the dangers of chemical methods of synthesis to an extent (Sundrarajan et al. 2015). When ZnO NPs come in contact with the water body, they induce oxidative stress to the aquatic animals (Connolly et al. 2016). But no information is available on the toxic effects of dietary ZnO NPs. In this context, we aim to compare the health effects of bio inspired green $\mathrm{ZnO}$ NPs and chemically synthesized $\mathrm{ZnO} \mathrm{NP}-$ enriched feed on Nile tilapia (Oreochromis niloticus). Nile tilapia is one of the most popular farmed fish species that has a good market value, can tolerate stress and is considered as an ideal organism for ecotoxicological studies (Abarike et al. 2019; Hasan Kaya et al. 2015). For green synthesis of $\mathrm{ZnO}$ NPs, Leucas aspera aqueous extract and oxycyclodextrin complex (oxy-CD complex) are used. Oxy-CD complex is a water-soluble compound of oxyresveratrol. It is prepared as an inclusion complex based on the method of Nasapon et al. (2010) Oxyresveratrol is a polyphenol, mainly 1, 4', 3, 5'-tetra hydroxy stilbene. Cyclodextrin forms an inclusion complex by improving the physicochemical properties with other guest molecules without altering the original structure (Venuti et al. 2014). Leucas aspera (Willd.) Linn. (Family: Lamiaceae) also known as 'thumbai' is distributed throughout India and is traditionally used as an antipyretic and insecticide (Suganya et al. 2014). L. aspera contains medicinally active compounds such as triterpenoids, diterpenes, oleanolic acid, ursolic acid and b-sitosterol, sterols, glucoside, phenolic compounds (4-(24-hydroxy-1-oxo-5-npropyltetracosanyl)-phenol) and hence is pharmacologically relevant. Our previous study has reported that the inclusion of plants in the diet of Nile tilapia improves immunity (Musthafa et al. 2018) and our recent study reported that L. aspera in the diet of Nile tilapia enhances immunity and disease resistance against Aeromonas hydrophila (Kurian et al. 2019). There are limited studies in Nile tilapia on the effects of nanofeed on bioaccumulation, oxidative stress response, DNA damage and immunological effects. Hence this study investigates and compares in depth the impacts of green and chemically synthesized nanozinc feed on the health status of Nile tilapia. The outcome of this study can be taken into consideration to decide whether nanozinc feed can be recommended as a safe alternative to conventional fish feeds.

\section{Materials and Methods}

\section{Preparation of Leucas aspera extract}

L. aspera plants were grown in the campus of Kerala University of Fisheries and Ocean Studies. Fresh L. aspera plants were collected from the campus in April 2019 and the aerial parts were rinsed completely in distilled water, chopped and shade dried for around 10 days and ground into fine powder according to Suganya et al. (2014). Five grams of plant powder was added into a conical flask containing $50 \mathrm{ml}$ distilled water and boiled for $20 \mathrm{~min}$. The aqueous extract was filtered using Whatman No.1 filter paper and stored at $4{ }^{\circ} \mathrm{C}$.

\section{Oxy-cyclodextrin complex}

Oxy-cyclodextrin was a kind gift from Dr. Sreeja lakshmi, DHR Research Scientist, KUFOS, Kerala, India.

\section{Green synthesis and chemical synthesis of zinc oxide nanoparticles}

The synthesis of zinc oxide nanoparticles was based on the coprecipitation method described by Singh et al. (2011). Starting materials used were zinc acetate dihydrate $\left(\mathrm{Zn}\left(\mathrm{CH}_{3} \mathrm{COO}\right)_{2}\right.$ $2 \mathrm{H}_{2} \mathrm{O}$; Merck) and sodium hydroxide ( $\mathrm{NaOH}$; Merck). A total of $2 \mathrm{M}$ zinc acetate in $50 \mathrm{ml}$ distilled water was prepared under constant stirring. To this, $50 \mathrm{ml}$ of $2 \mathrm{M} \mathrm{NaOH}$ was added after complete dissolution of zinc acetate. The mixture was kept in a magnetic stirrer for $2 \mathrm{~h}$. The white precipitate formed was filtered and washed with distilled water and ethanol (Merck) to remove impurities. The purified precipitate was kept in the oven at $60{ }^{\circ} \mathrm{C}$ for overnight drying and the resultant solid white powder was kept for calcination in a muffle furnace at $300{ }^{\circ} \mathrm{C}$ for $3 \mathrm{~h}$. For green synthesis of zinc oxide nanoparticles, $5 \mathrm{ml}$ of plant extract, $5 \mathrm{ml}$ of oxyresveratrol and $50 \mathrm{ml}$ of $2 \mathrm{M} \mathrm{NaOH}$ were added to $50 \mathrm{ml}$ of $2 \mathrm{M}$ zinc acetate solution. The off-white precipitate formed was filtered and washed with distilled water and ethanol to remove impurities. The purified precipitate was kept in the oven at $60{ }^{\circ} \mathrm{C}$ for overnight drying and the resultant solid off-white powder was kept for calcination in the muffle furnace at $300{ }^{\circ} \mathrm{C}$ for $3 \mathrm{~h}$.

\section{Characterization of nanoparticles}

For understanding various physicochemical features, nanoparticles were characterized by UV-Vis spectroscopy analysis (UV-1800 Shimadzu, Japan), XRD (Bruker D8 advance, Germany), FTIR (IRaffinity 1, Shimadzu, Japan), Zeta potential (Malvern Zetasizer, UK), SEM (EVO 18 Carl Zeiss, Germany) and TEM (FEI-Tecnai G2 20, USA)

\section{In vitro antioxidant activity}

\section{DPPH free radical scavenging assay}

DPPH free radical scavenging activity was measured by the method of Das et al. (2013) with modification. Various concentrations of $\mathrm{ZnO}$ NP solution (25, 75, 100, 200, 400, 600 and $800 \mu \mathrm{g} / \mathrm{ml})$ in methanol $(4 \mathrm{ml})$ was mixed with $1 \mathrm{ml}$ of freshly prepared DPPH (HiMedia; $0.1 \mathrm{mM}$ in $100 \%$ methanol; Merck), the mixture was shaken vigorously and incubated for $30 \mathrm{~min}$ at room temperature in the dark. The absorbance was 
measured at $517 \mathrm{~nm}$ against methanol blank in a UV-Vis spectrophotometer (UV-1800 Shimadzu, Japan). DPPH scavenging activity is calculated by the following equation

Scavenging activity $(\%)=100 \times\left(A_{\mathrm{c}}-A_{\mathrm{s}}\right) / A_{\mathrm{c}}$

$A_{\mathrm{c}}$ and $A_{\mathrm{s}}$ are absorbance of control and sample respectively.

\section{Reducing power assay}

The reducing power was determined by Oyaizu's method (1986) with minor modifications. Different concentrations of $1 \mathrm{ml}$ of ZnO NP solution $(25,75,100,200,400,600$ and 800 $\mu \mathrm{g} / \mathrm{ml})$ was mixed with $2.5 \mathrm{ml}$ of phosphate buffer $(0.2 \mathrm{M}, \mathrm{Ph}$ 6.6) and $2.5 \mathrm{ml}$ of potassium ferricyanide (HiMedia) and kept at $50{ }^{\circ} \mathrm{C}$ for $20 \mathrm{~min}$ in a water bath. $2.5 \mathrm{ml}$ of $10 \%$ trichloroacetic acid (TCA; Merck) was added to terminate the reaction and centrifuged at $4000 \mathrm{rpm}$ for $5 \mathrm{~min} .2 .5 \mathrm{ml}$ of the upper layer was diluted with $2.5 \mathrm{ml}$ of distilled water and $0.5 \mathrm{ml}$ of $0.1 \%$ ferric chloride (HiMedia) was added. The absorbance was measured at $700 \mathrm{~nm}$ in a UV-Vis spectrophotometer (UV1800 Shimadzu, Japan). Reducing power was represented in the form of optical density (OD). The higher the OD, the higher the reducing power.

\section{Antibacterial activity}

Aeromonas hydrophila (A. hydrophila) and Streptococcus agalactiae (S. agalactiae) obtained from CUSAT (Cochin University of Science and Technology), Kochi, Kerala, was sub-cultured for $24 \mathrm{~h}$ at $37{ }^{\circ} \mathrm{C}$ with agitation to mid-log growth phase and colonies were confirmed as Aeromonas and Streptococcus using Aeromonas special media (HiMedia) and S. agalactiae selective agar base prior to use. Antibacterial activity of $\mathrm{ZnO}$ NPs against Aeromonas hydrophila (A. hydrophila) and Streptococcus agalactiae ( $S$. agalactiae) were tested using the Kirby-Bauer et al. (1966) disc diffusion method. Bacteria strains were spread uniformly on the nutrient agar plates using sterile cotton swabs. Filter paper discs were placed on the agar plates and were loaded with different concentrations of both types of $\mathrm{ZnO}$ NPs $(25,50$ and $75 \mu \mathrm{g} / \mathrm{ml})$ and incubated at $37^{\circ} \mathrm{C}$ for $24 \mathrm{~h}$. The zone of inhibition was observed after $24 \mathrm{~h}$ of incubation.

\section{Fish and experimental design}

Six hundred Nile tilapia were purchased from a fish farm in Alleppey district, Kerala, and were transported to the laboratory. Fish were acclimatized for 14 days in a 1000-L aerated fibre tank and were fed commercial feed (No 9951, CPF company, India; protein content $-33.8 \mathrm{~g} \mathrm{~kg}^{-1}$ dry matter basis, lipid content $-6.448 \mathrm{~g} \mathrm{~kg}^{-1}$ dry matter basis). Then, 5 fish were randomly caught to check the health status by examining the gills and internal organs observation under a light microscope. After the acclimatization period, 420 fish were distributed randomly into 21 glass tanks (150 L; 20 fish per tank; average weight $=20.11 \pm 0.14 \mathrm{~g}$ ) with three replicates per treatment. Throughout the experiment, water quality parameters were monitored daily at $9.30 \mathrm{a} . \mathrm{m}$. and $5.30 \mathrm{p} . \mathrm{m}$. and parameters like $\mathrm{pH}$, temperature, nitrite level, ammonia and dissolved oxygen were tested prior to the study. The $\mathrm{pH}$ and temperature were determined by conventional methods whereas dissolved oxygen was measured using manganese oxidation capacity. An API freshwater master test kit was used for checking ammonia and nitrite. Water was changed daily up to $50 \%$ to regulate these parameters: water temperature $28 \pm 2{ }^{\circ} \mathrm{C}, \mathrm{pH} 7.7 \pm 0.24$ and dissolved oxygen $5.1 \pm 0.31 \mathrm{mg} / \mathrm{L}$. The following diets were fed to fish for 60 days.

(i) Control tank- Not exposed to ZnO NPs, fed with control diet

(ii) GT1 - Fish that received green synthesized ZnO NPs at concentration $100 \mathrm{mg} / \mathrm{kg}$

(iii) $\mathrm{CT} 1$ - Fish that received chemically synthesized $\mathrm{ZnO}$ NPs at concentration $100 \mathrm{mg} / \mathrm{kg}$

(iv) GT2 - Fish that received green synthesized $\mathrm{ZnO}$ NPs at concentration $200 \mathrm{mg} / \mathrm{kg}$

(v) CT2-Fish that received chemically synthesized $\mathrm{ZnO}$ NPs at concentration $200 \mathrm{mg} / \mathrm{kg}$

(vi) GT3-Fish that received green synthesized ZnO NPs at concentration $400 \mathrm{mg} / \mathrm{kg}$

(vii) CT3-Fish that received chemically synthesized $\mathrm{ZnO}$ NPs at concentration $400 \mathrm{mg} / \mathrm{kg}$

To prepare the nanozinc-enriched diets, green synthesized and chemically synthesized $\mathrm{ZnO}$ NP powders were weighed (GT1-100 mg, GT2-200 mg, GT3-400 mg; CT1-100 $\mathrm{mg}, \mathrm{CT} 2-200 \mathrm{mg}, \mathrm{CT} 3-400 \mathrm{mg}$ ) and dispersed into vegetable oil $(20 \mathrm{ml})$ in separate containers. The doses were chosen based on environmentally relevant concentrations described by Anu et al. (2014). To each of the containers, conventional diet was added and mixed properly to prepare different treatment diets. Similarly, control diet was prepared by mixing the same volume of vegetable oil per kilogramme. The prepared diets were left open in the containers for the oil to get absorbed into the feeds. After completion of drying, the feeds were stored in a cool and dry place. Fish in each replication were fed ad libitum twice a day at 9:00 a.m. and 5:00 p.m. for 60 days. The remaining feed and metabolic wastes were siphoned out daily and renewed water in each tank.

Fish were stopped giving feed $24 \mathrm{~h}$ before sample collection. At the end of the feeding trial, four fish were randomly caught from each tank and were anaesthetized with clove oil $\left(5 \mathrm{ml} \mathrm{L}^{-1}\right)$, followed by blood collection from the caudal vein with a $1 \mathrm{ml}$ plastic syringe sprayed with heparin (HiMedia) and stored at $4{ }^{\circ} \mathrm{C}$ until the next day. Serum was prepared as described by Doan et al. (2016). Using a 1-ml syringe, blood 
was collected from the caudal vein. The collected blood samples were immediately transferred into Eppendorf tubes and were allowed to clot for $1 \mathrm{~h}$ at room temperature and $4 \mathrm{~h}$ at 4 ${ }^{\circ} \mathrm{C}$. The samples were centrifuged at $1500 \times \mathrm{g}$, for $5 \mathrm{~min}$, at 4 ${ }^{\circ} \mathrm{C}$ in a cooling centrifuge (Heraeus Thermo Scientific Megafuge 8R, Germany). The serum was finally collected and stored at $-20^{\circ} \mathrm{C}$ until assay. At the end of the feeding period, gills and liver from each group were collected, weighed, homogenized in potassium phosphate buffer $(50$ $\mathrm{mM}, \mathrm{pH}$ 7.0) and centrifuged at $10,000 \mathrm{rpm}$ for $10 \mathrm{~min}$ at 4 ${ }^{\circ} \mathrm{C}$. The supernatant collected was used for determining the antioxidant enzyme activities. The concentration of protein in tissue homogenates was measured according to the method of Lowry et al. (1951), using bovine serum albumin (HiMedia) as standard.

\section{Enzymatic antioxidant activity}

\section{Estimation of catalase}

Catalase activity was estimated by the method of Hugo E Aebi (1974). To $1 \mathrm{ml}$ phosphate buffer (50 mM, pH 7.0), $100 \mu \mathrm{l}$ of supernatant was added followed by the addition of $0.5 \mathrm{ml}$ of freshly prepared hydrogen peroxide ( $30 \mathrm{mM}$; Sigma Aldrich). After adding $2 \mathrm{ml}$ dichromate acetic acid solution (HiMedia), the tubes were placed for $10 \mathrm{~min}$ in a boiling water bath and was read at $240 \mathrm{~nm}$ by calculation (Decrease in absorbance $\times$ 100/1) divided by protein amount in mg divided by time in $\min =$ units $/ \mathrm{mg}$ protein $/ \mathrm{min}$.

\section{Estimation of superoxide dismutase}

Superoxide dismutase was estimated by the method of Paoletti and Mocali (1990) by assessing the inhibition of NADH oxidation using $\beta$-mercaptoethanol (Merck) in the presence of EDTA (Sigma Aldrich) and Mn as a substrate. The assays were run by adding to the cuvette sequentially $0.80 \mathrm{ml}$ of $50 \mathrm{mM}$ phosphate buffer ( $\mathrm{pH}$ 7.4), $55 \mu$ EDTA/Mn solution of 100/50 mM, $40 \mu \mathrm{l} \mathrm{NADH} \mathrm{solution} \mathrm{(Sigma} \mathrm{Aldrich)} \mathrm{of} 7.5$ $\mathrm{mM}$, and different volumes of tissue extract. The reaction was then initiated by adding $100 \mu \mathrm{l} 10 \mathrm{mM} \beta$-mercaptoethanol solution. The change in the absorbance of NADH at $340 \mathrm{~nm}$ per min was noted followed by calculating the enzyme activity from the calibration curve.

\section{Estimation of glutathione peroxidase and reduced glutathione}

GPx activity was measured using 5, 5, dithiobistetranitrobenzoic acid (DTNB) reagent (Sigma Aldrich), according to Hafeman et al. (1974). Briefly, the samples were incubated at $37^{\circ} \mathrm{C}$ for $5 \mathrm{~min}$ with a solution containing $80 \mathrm{mM}$ sodium phosphate buffer ( $\mathrm{pH}$ 7.0), $80 \mathrm{mM}$ EDTA, $1 \mathrm{mM}$ sodium azide ( $\mathrm{NaN}_{3}$ :HiMedia), $0.4 \mathrm{mM} \mathrm{GSH}$, and $0.25 \mathrm{mM}$ hydrogen peroxide (reagent solution). The reaction was stopped by adding metaphosphoric acid solution for protein precipitation. After centrifugation, the remaining GSH in the supernatant was determined using $0.4 \mathrm{M}$ sodium phosphate buffer (pH 7.0) and $1 \mathrm{mM}$ DTNB in $1 \%$ trisodium citrate solution, and then it was measured at $412 \mathrm{~nm}$ according to Boyne and Ellman (1972) where the enzyme activity is expressed in terms of $\mu \mathrm{g}$ of glutathione utilized $/ \mathrm{min} / \mathrm{mg}$ protein.

\section{Estimation of glutathione reductase}

Glutathione reductase was measured according to the method of Goldberg and Spooner (1983). To $0.2 \mathrm{ml}$ of the sample, $1.5 \mathrm{ml}$ of phosphate buffer, $0.5 \mathrm{ml}$ of EDTA, $0.2 \mathrm{ml}$ of oxidized glutathione (HiMedia) and $0.1 \mathrm{ml}$ NADPH (HiMedia) were added. The decrease in the optical density of the enzyme was measured against that of the blank at $340 \mathrm{~nm}$. The enzyme activity has been expressed as nM NADPH oxidized to $\mathrm{NADP} / \mathrm{mg}$ of protein/min by using the molar extinction coefficient of $6200 / \mathrm{M} / \mathrm{cm}$ at $340 \mathrm{~nm}$.

\section{Innate immunological response}

\section{Lysozyme assay}

Lysozyme activity was determined by the protocol described by Parry et al. (1965). $25 \mu \mathrm{l}$ of serum was added to $175 \mu \mathrm{l}$ of M. lysodiekticus (Sigma Aldrich) suspension $0.3 \mathrm{mg} \mathrm{ml}^{-1}$ in $0.1 \mathrm{M}$ phosphate citrate buffer, $\mathrm{pH}$ 5.8. After a rapid mixing, the change in turbidity was measured every $30 \mathrm{~s}$ for $5 \mathrm{~min}$ at $540 \mathrm{~nm}$ at approximately $25^{\circ} \mathrm{C}$ using a micro-plate reader. The equivalent unit of the activity of the sample (compared with the standard) were determined and expressed in $\mu \mathrm{g} \mathrm{ml}^{-1}$ serum. Delta T\% $(y)=[$ Abs (0 s $)-$ Abs $(300 s)] \times 100$.

\section{Respiratory burst activity}

Respiratory burst activity was carried out as described by Anderson and Siwicki (1995) for measuring the production of oxygen radicals from phagocytes. $0.1 \mathrm{ml}$ of heparinized blood was placed into a microtiter plate and equal amount of $0.2 \%$ NBT (Merck) was added and incubated for $30 \mathrm{~min}$ at room temperature. To a glass tube containing $1.0 \mathrm{ml}$ of N, Ndimethylformamide solution (Merck), $0.05 \mathrm{ml}$ of the NBTblood cell suspension was added. Then the mixture was centrifuged at $3000 \mathrm{~g}$ for $5 \mathrm{~min}$. The absorbance of the supernatant taken into a glass cuvette was read at $540 \mathrm{~nm}$ using a spectrophotometer. Spontaneous $\mathrm{O}_{2}{ }^{-}$production $=(\mathrm{Abs}$ NBT reduction of sample) - (Abs of blank). 


\section{Myeloperoxidase activity}

Peroxidase activity was determined following the methods of Quade and Roth (1997). $5 \mu \mathrm{L}$ of serum was placed in a flat bottomed 96-well plate in triplicates. Thereafter, $45 \mu \mathrm{L}$ of Hank's balanced salt solution (HBSS; Merck) without $\mathrm{Ca}^{2+}$ or $\mathrm{Mg}^{2+}$ and $100 \mu \mathrm{L}$ of solution (40 $\mathrm{ml}$ of distilled water, 10 $\mu \mathrm{L}$ of $\mathrm{H} 2 \mathrm{O} 2$ (30\%-Sigma-Aldrich), 1 pill of $3,3^{\prime}, 5,5^{\prime}-$ tetramethylbenzidine (TMB; Sigma Aldrich) were added. 50 $\mu \mathrm{L} 2 \mathrm{M} \mathrm{H}_{2} \mathrm{SO}_{4}$ was added immediately once the colour change appeared and the optical density was read at $450 \mathrm{~nm}$ in a plate reader. One unit was defined as the amount producing an absorbance change of 1 and the activity was expressed as units (U) $\mathrm{mg}^{-1}$ serum or mucus proteins.

\section{Histology}

For histopathology study of gills and liver, tissues were processed following the methods described by Humason (1979) and Pearse (1968). Gills and liver were fixed for $24 \mathrm{~h}$ in $10 \%$ formalin solution before embedding in paraffin wax. Sections of the liver and gills were stained with haematoxylin and eosin and were analysed for histopathological alterations.

\section{Inductively coupled plasma mass spectrometry}

Gills, liver and muscle samples were prepared for ICP-MS as described by Shahzad et al. (2017). $10 \mathrm{ml}$ concentrated nitric acid and $2 \mathrm{ml}$ of perchloric acid were added to $1 \mathrm{~g}$ of freezedried samples which were digested by heating in a hot plate at $100{ }^{\circ} \mathrm{C}$. Two drops of hydrogen peroxide were added to the samples which were then diluted with distilled water and finally were filtered with a Whatman filter paper.

\section{Determination of DNA damage marker 8-hydroxy-2-deoxyguanosine}

8-Hydroxy-2-deoxyguanosine (8-OHdG), a biomarker of oxidative DNA damage was measured with the highly sensitive 8-OHdG competitive ELISA kit (Cellbiolabs, USA). For the quantification of 8-OHdG, blood plasma was collected from the blood of four fish by centrifugation for $5 \mathrm{~min}$ at $5000 \mathrm{~g}$ and stored at $-18^{\circ}$ until analysis.

\section{Statistical analysis}

One-way ANOVA and Duncan's multiple range test (DMRT) were used to determine the significant differences between the means using SPSS version 16 for windows. Mean values were considered significantly different when $P<0.05$. Data are presented as means \pm standard deviation. Histology results were not statistically analysed, but visually examined.

\section{Results}

\section{Characterization of zinc oxide nanoparticles}

The colour of the solution for chemically synthesized $\mathrm{ZnO}$ NPs was observed to be white, whereas the colour of green synthesized ZnO NPs showed a pale white colour. The UVVis absorption spectrum of chemically synthesized ZnO NPs exhibited an absorption wavelength of $360 \mathrm{~nm}$ (Fig. 1) and that of green synthesized $\mathrm{ZnO}$ NPs was $350 \mathrm{~nm}$ (Fig. 1).

$\mathrm{X}$-ray diffraction pattern (XRD) of chemically synthesized $\mathrm{ZnO}$ NPs showed $2 \theta$ values at $32.01^{\circ}(100), 34.66^{\circ}(002)$, $36.51^{\circ}(101), 47.75^{\circ}(102), 56.88^{\circ}(110), 63.04^{\circ}(103)$ and $66.60^{\circ}(200)$ and that of green synthesized $\mathrm{ZnO}$ NPs exhibited $2 \theta$ values at $32.0^{\circ}(100), 34.65^{\circ}(002), 36.47^{\circ}(101), 47.72^{\circ}$ $(102), 56.79^{\circ}(110), 63.03^{\circ}(103)$ and $66.58^{\circ}$ (200) corresponding with the Joint Committee on Powder Diffraction Standard (JCPDS) Card No. 89-1397 (Fig. 2a, b). The peaks observed were the indication of the wurtzite structure of zinc oxide. The average crystallite size of chemically synthesized $\mathrm{ZnO}$ NPs and green synthesized $\mathrm{ZnO}$ NPs were calculated as $29.5 \mathrm{~nm}$ and $35.10 \mathrm{~nm}$ respectively as calculated by the Scherrer equation.

Figure $3 \mathrm{a}$ and $\mathrm{b}$ show the FTIR absorption spectrum of chemically synthesized $\mathrm{ZnO}$ NPs and green synthesized $\mathrm{ZnO}$ NPs respectively. The peak at $455.20 \mathrm{~cm}^{-1}$ indicates absorption of $\mathrm{ZnO}$ bond and the broad absorption peak at 3385.07 $\mathrm{cm}^{-1}$ can be attributed to the absorption of hydroxyl (Fig. 3a). In the spectra of green synthesized $\mathrm{ZnO}$ NPs, the peak at

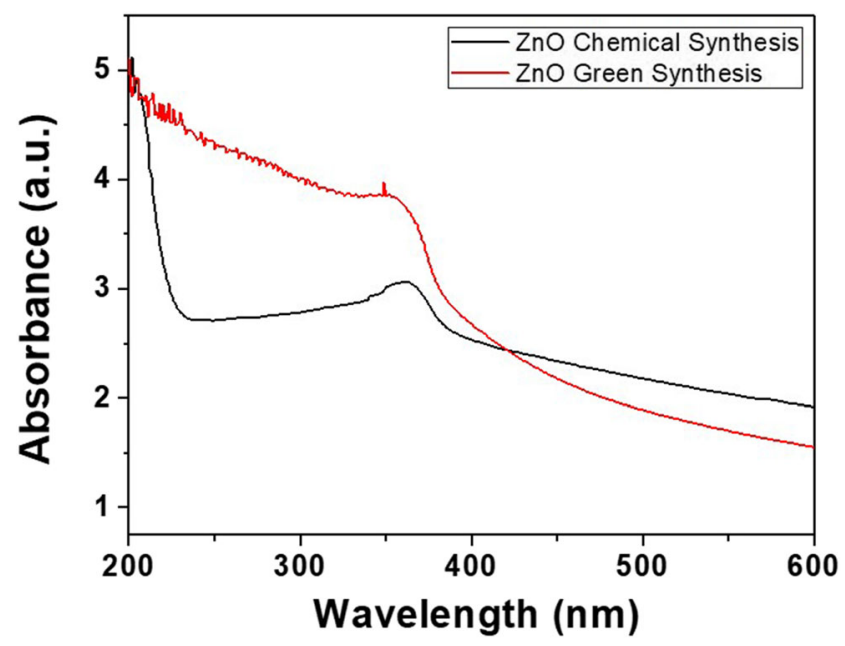

Fig. 1 a UV-Vis spectrum of chemically synthesized ZnO NPs. b UVVis spectrum of green synthesized ZnO NPs 
Fig. 2 a XRD pattern of chemically synthesized $\mathrm{ZnO}$ NPs. b XRD pattern of green synthesized $\mathrm{ZnO}$ NPs
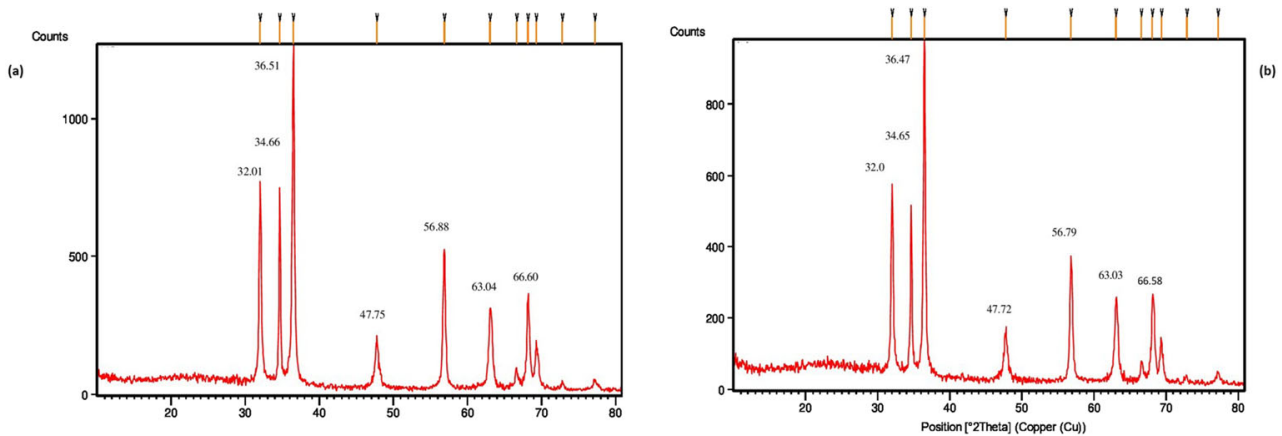

$885.33 \mathrm{~cm}^{-1}$ is probably linked to $\mathrm{ZnO}$ whereas the broad absorption peak at $3360 \mathrm{~cm}^{-1}$ can be assigned to hydrogen bonded in alcohol or phenol groups (Fig. 3b).

Zeta potential of chemically synthesized ZnO NPs and green synthesized $\mathrm{ZnO}$ NPs were determined in water as a dispersant. The measurement demonstrated that chemically synthesized ZnO NPs have a zeta potential of $-16.6 \mathrm{mV}$ (Fig. 4a) and that of green synthesized $\mathrm{ZnO}$ NPs have a zeta potential of $-24.5 \mathrm{mV}$ (Fig. 4b). TEM images determined the morphological features of nanoparticles (Fig. 5a-d). The TEM image of green synthesized nanoparticles shows mostly spherical shapes with a few rod shapes, whereas the chemically synthesized nanoparticles display agglomeration of different shaped particles such as triangles, rods, spheres and hexagonal shapes.

\section{In vitro antioxidant activity}

Antioxidant capacity of chemically synthesized ZnO NPs and green synthesized ZnO NPs were estimated by DPPH assay and reducing power assay. In DPPH assay, the antioxidant activity of chemically synthesized $\mathrm{ZnO}$ NPs and green synthesized ZnO NPs improved as the concentration of samples increased from 25 to $800 \mu \mathrm{g} / \mathrm{ml}$ (Fig. 6a) and a colour change was observed from deep violet to pale yellow. It was observed that the free radical scavenging activity of green synthesized $\mathrm{ZnO}$ NPs increased in a concentration-dependent manner. Also, it was observed that the antioxidant potential of green synthesized $\mathrm{ZnO}$ NPs was significant to chemically

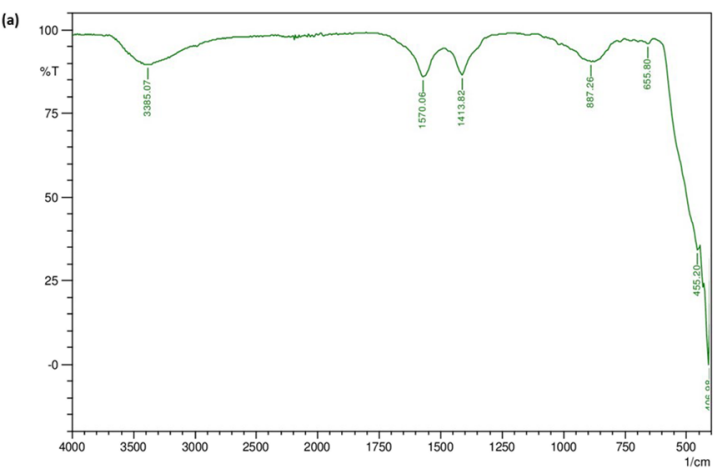

synthesized ZnO NPs. Thus, green synthesized ZnO NPs exhibited better antioxidant property than chemically synthesized $\mathrm{ZnO}$ NPs.

In reducing power assay, a change in colour was observed at $700 \mathrm{~nm}$ from yellow to shades of blue or green. As per the results, the reducing activity of green synthesized ZnO NPs was higher than chemically synthesized ZnO NPs. Reducing activity was observed to be increasing as the concentration increased (Fig. 6b).

\section{Antibacterial activity}

The antibacterial activity of green synthesized and chemically synthesized $\mathrm{ZnO}$ NPs were investigated against gramnegative A. hydrophila and gram-positive $S$. agalactiae with three different concentrations $(25,50$ and $75 \mu \mathrm{g} / \mathrm{ml})$ by KirbyBauer disc diffusion method (Fig. 7a-d). Among the tested pathogens, A. hydrophila exhibited higher sensitivity toward green synthesized $\mathrm{ZnO}$ NPs with $35 \mathrm{~mm}$ zone of inhibition at the highest concentration $(75 \mu \mathrm{g} / \mathrm{ml})$ while the zone of inhibition at the highest concentration of chemically synthesized $\mathrm{ZnO}$ NPs was $32 \mathrm{~mm}$. On the other hand, S. agalactiae too exhibited higher sensitivity to green synthesized ZnO NPs at the highest concentration with a 31-mm zone of inhibition and the zone of inhibition was $29 \mathrm{~mm}$ in the plate of chemically synthesized ZnO NPs. This implies that both gram-positive and gram-negative bacteria seemed to have less resistance to green synthesized ZnO NPs when compared with chemically synthesized $\mathrm{ZnO}$ NPs.

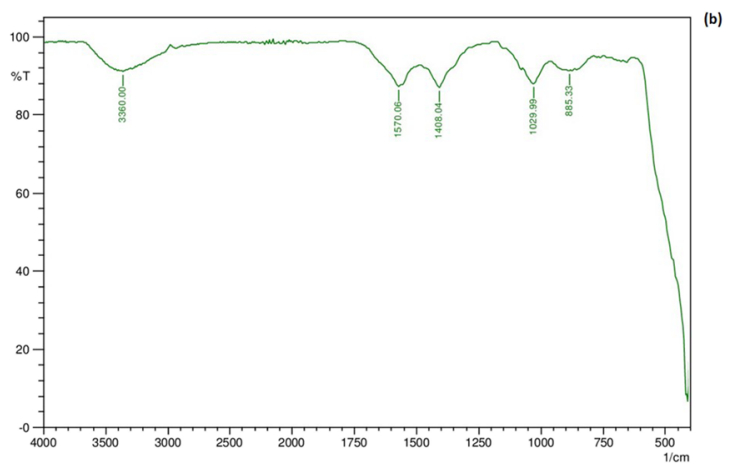

Fig. 3 a FTIR spectra of chemically synthesized ZnO NPs. b FTIR spectra of green synthesized ZnO NPs 
(a)

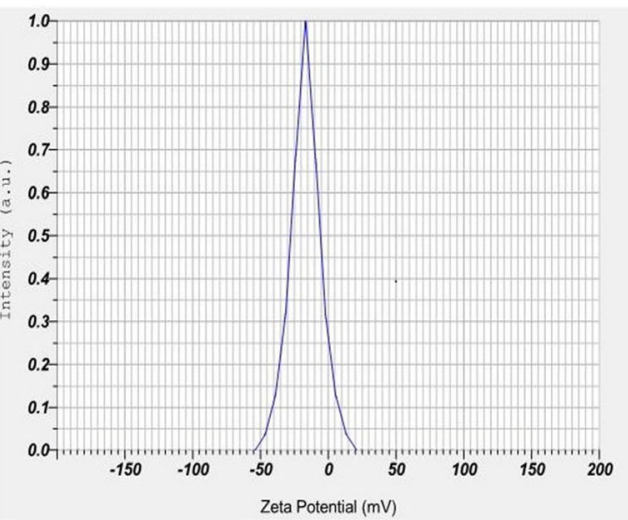

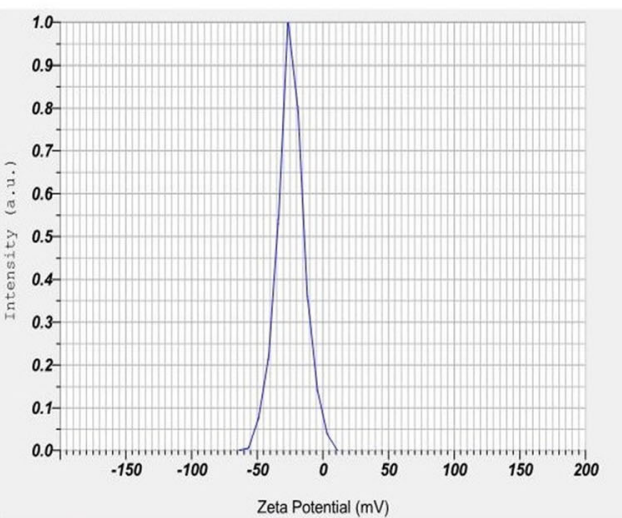

(b)

Fig. 4. a Zeta potential of chemically synthesized ZnO NPs. b Zeta potential of green synthesized ZnO NPs

\section{Enzymatic and non-enzymatic antioxidant enzymes}

Fish that were fed green synthesized ZnO NPs at all concentrations (100 mg/kg, $200 \mathrm{mg} / \mathrm{kg}$ and $400 \mathrm{mg} / \mathrm{kg}$ ) significantly
$(P<0.05)$ enhanced catalase (CAT) activity, glutathione peroxidase (GPx) and superoxide dismutase (SOD) in the liver and gills in a concentration dependent manner. On the other hand, chemically synthesized $\mathrm{ZnO}$ NPs at all three (a)

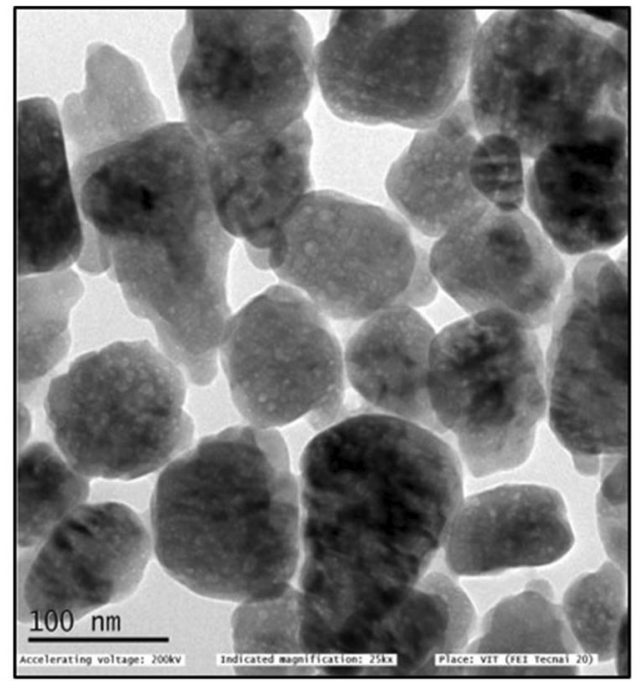

(c)

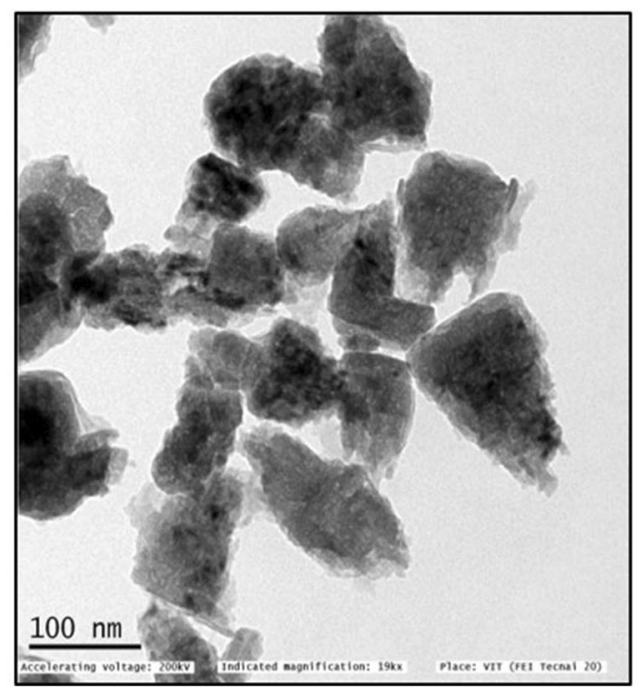

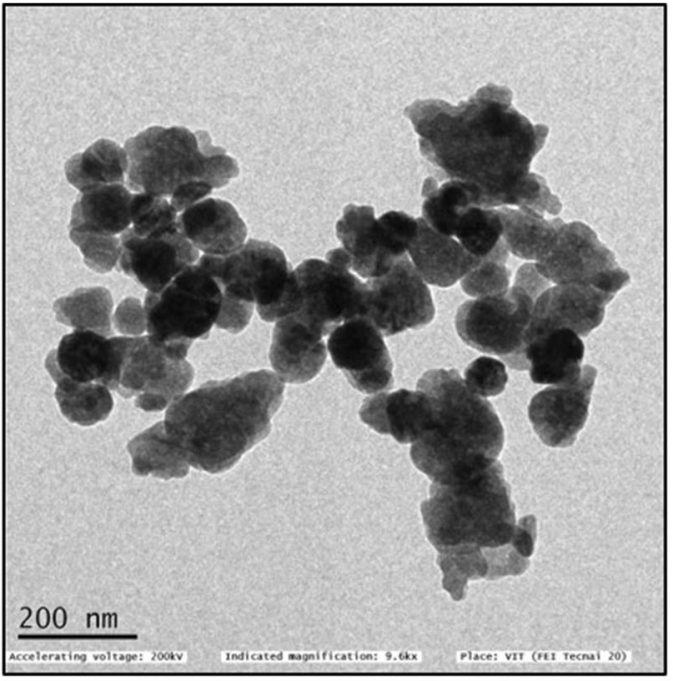

(b)

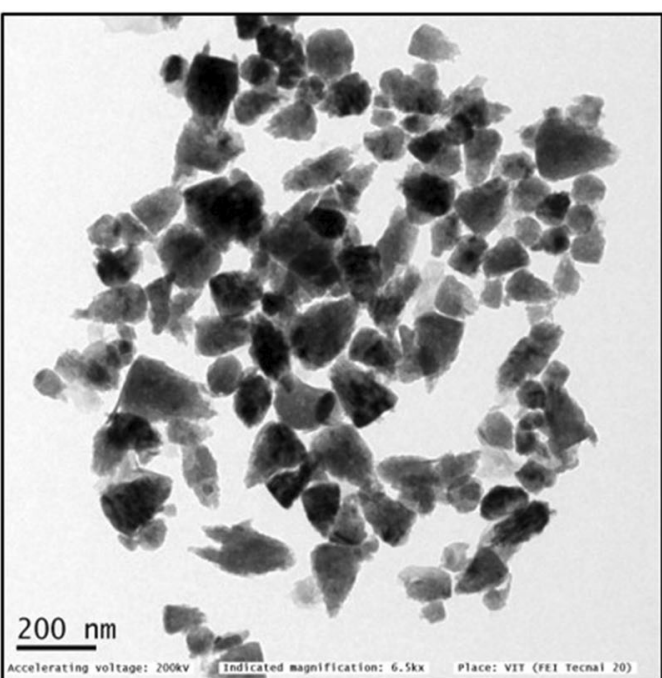

(d)

Fig. 5 a, b TEM images of chemically synthesized ZnO NP at $100 \mathrm{~nm}$ and $200 \mathrm{~nm}$ respectively. c, d TEM images of green synthesized ZnO NP at $100 \mathrm{~nm}$ and $200 \mathrm{~nm}$ respectively 
Fig. 6 a DPPH activity of chemically synthesized and green synthesized ZnO NP. Bars assigned with different superscripts are significantly different $(P<0.05)$. b Reducing power activity of chemically synthesized and green synthesized $\mathrm{ZnO} \mathrm{NP}$. Bars assigned with different superscripts are significantly different $(P<0.05)$ (a)

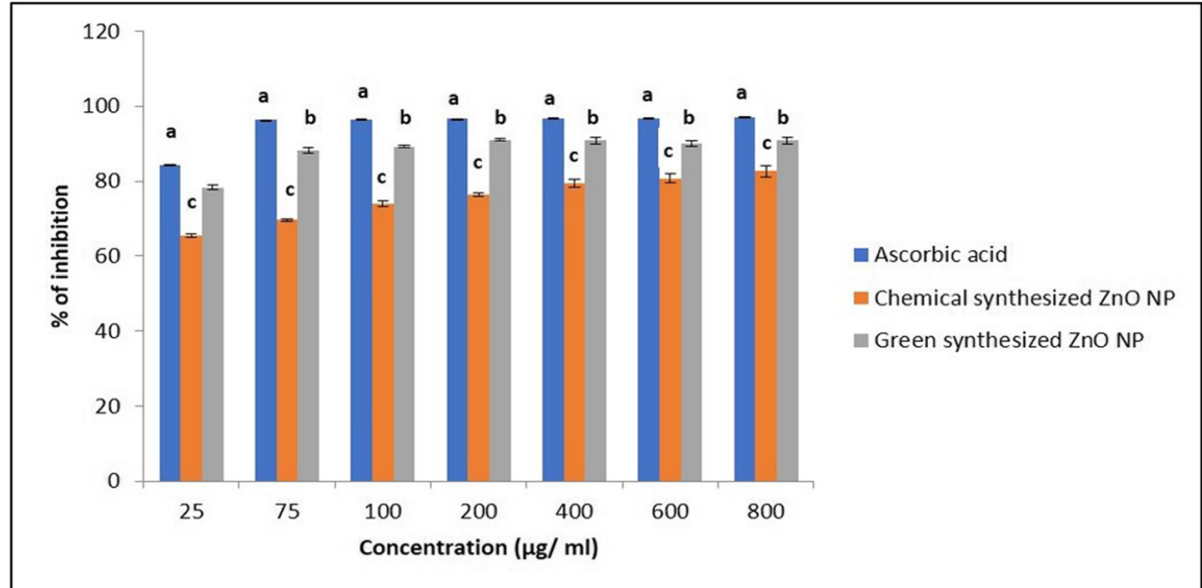

(b)

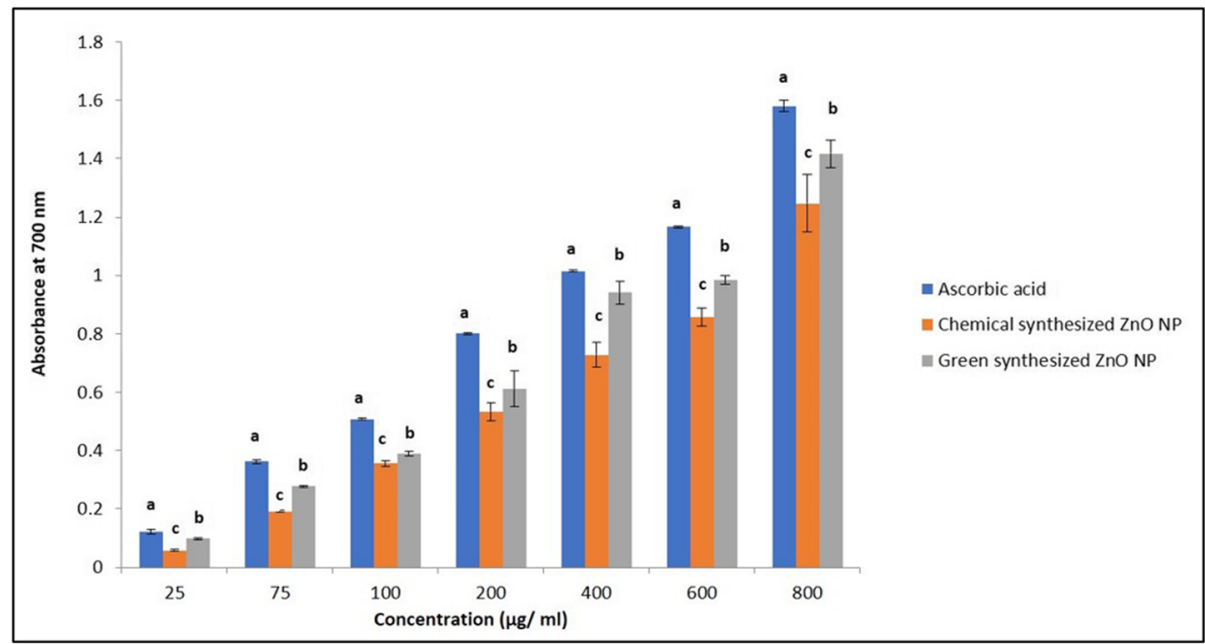

concentrations $(100 \mathrm{mg} / \mathrm{kg}, 200 \mathrm{mg} / \mathrm{kg}$ and $400 \mathrm{mg} / \mathrm{kg}$ ) inhibited the activity of CAT, GPx and SOD in the liver and gills (Fig. 8a-e).

All concentrations of green synthesized $\mathrm{ZnO}$ NP feeds (GT1, GT2 and GT3) significantly $(P<0.05)$ augmented the activity of glutathione reductase (GR) and reduced glutathione (GSH) in the gills and liver as the concentration increased; however, fish fed chemically synthesized ZnO NP feed induced a significant decline in the activity of GR and GSH in both the liver and gills with the least activity observed in CT3.

\section{Innate immunological response}

\section{Lysozyme activity}

Results of lysozyme activity revealed that green synthesized $\mathrm{ZnO}$ NP feeds and chemically synthesized $\mathrm{ZnO}$ NP feeds significantly $(P<0.05)$ increased lysozyme activity in Nile tilapia in a concentration-dependent manner when compared with the control (Fig. 9a). Maximum activity was detected in fish that were fed GT3 diet.

\section{Respiratory burst activity}

It was observed that all treatment groups exhibited significantly higher $(P<0.05)$ respiratory burst activity when compared with the control (Fig. 9b). Among all the treatment groups, maximum activity was observed in the fish that were fed GT3 diet.

\section{Myeloperoxidase activity}

Serum peroxidase activity was observed to be significantly higher $(P<0.05)$ in all treatment groups when compared with the control (Fig. 9c). Fish that were fed diet GT3 has the maximum peroxidase activity in the serum.

\section{Histology}

Effects of dietary intake of $\mathrm{ZnO}$ NP feeds on gills and liver histology of control and treatment groups are shown in Fig. $10 \mathrm{a}-\mathrm{f}$. In the control group, histological analysis of the liver revealed normal architectural arrangement with abundant hepatocytes $(\mathrm{H})$ with prominent nucleus and sinusoids (SI). Gills 

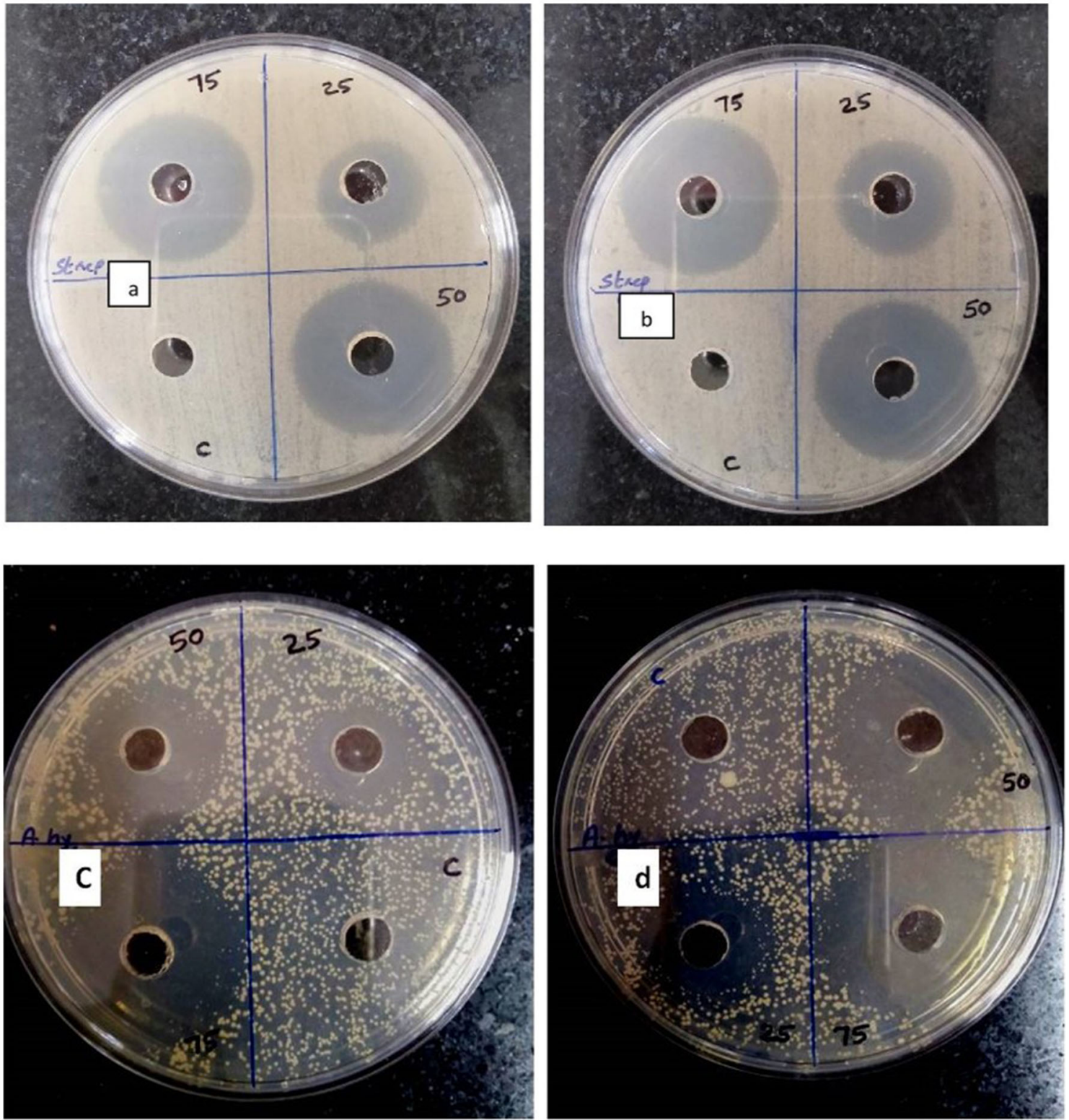

Fig. 7 a Zone of inhibition observed in chemically synthesized ZnO NP plates tested against Streptococcus agalactiae at 25-, $50-$ and $75-\mu \mathrm{g} / \mathrm{ml}$ concentrations. b Zone of inhibition observed in green synthesized $\mathrm{ZnO}$ NP plates tested against Streptococcus agalactiae at 25-, 50- and 75$\mu \mathrm{g} / \mathrm{ml}$ concentrations. c Zone of inhibition observed in chemically

of the control group also displayed normal structure with secondary gill lamellae (SGL), primary gill lamella (PGL), a single layer of epithelial cells supported by the pillar cells (PC). In the fish fed chemically synthesized ZnO NP feed, hepatocytes of the liver were observed to have moderate necrosis $(\mathrm{NH})$, with some areas showing amorphous aggregates of necrotic material (NC) and moderate congestion in blood sinusoids (HE). On the other hand, the histopathology of gills of fish fed chemically synthesized ZnO NP feed reported moderate epithelial hyperplasia, epithelial lifting (EL) and synthesized ZnO NP plates tested against Aeromonas hydrophila at 25-, $50-$ and $75-\mu \mathrm{g} / \mathrm{ml}$ concentrations. d Zone of inhibition observed in green synthesized ZnO NP plates tested against Aeromonas hydrophila at 25-, $50-$ and $75-\mu \mathrm{g} / \mathrm{ml}$ concentrations

inflammation (IN). But in the case of green synthesized $\mathrm{ZnO}$ $\mathrm{NP}-$ fed fish, both the liver and gills revealed normal histology.

\section{Inductively coupled plasma mass spectrometry}

The accumulation of zinc from $\mathrm{ZnO}$ NP feed was determined by ICP-MS analysis. Liver, gill and muscle samples of fish fed with the highest dose (CT3 and GT3) were selected for the analysis. From the studied tissues, the 

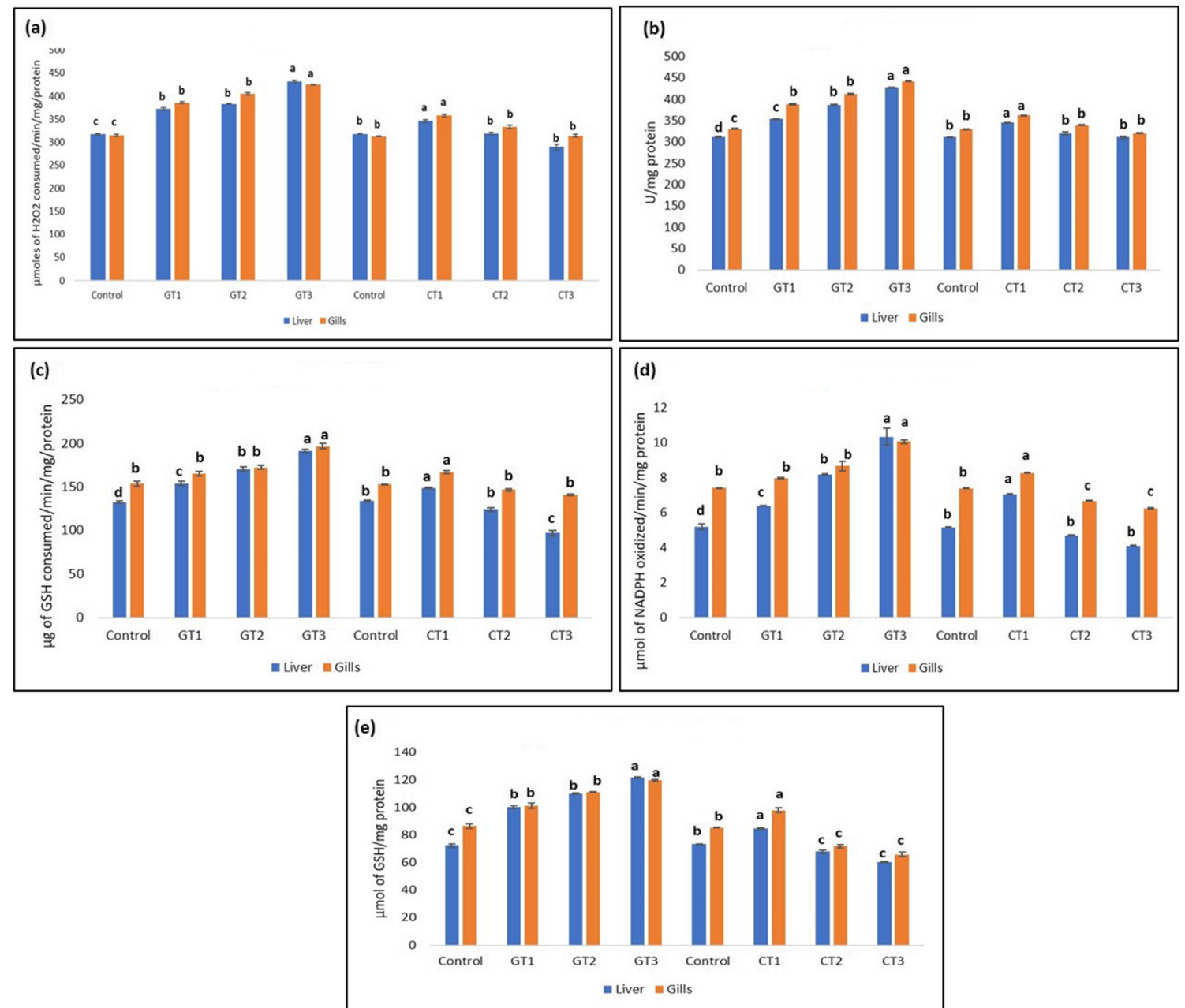

Fig. 8 a Activity of catalase (CAT) enzyme in the liver and gills in the control group and in GT1 - group fed green synthesized ZnO NPs at concentration $100 \mathrm{mg} / \mathrm{kg}, \mathrm{CT} 1$ - fish fed chemically synthesized $\mathrm{ZnO}$ NPs at concentration $100 \mathrm{mg} / \mathrm{kg}$, GT2 - fish fed green synthesized ZnO NPs at concentration $200 \mathrm{mg} / \mathrm{kg}$, CT2 - fish fed chemically synthesized $\mathrm{ZnO}$ NPs at concentration $200 \mathrm{mg} / \mathrm{kg}$, GT3 - fish fed green synthesized $\mathrm{ZnO}$ NPs at concentration $400 \mathrm{mg} / \mathrm{kg}$, CT3 - fish fed chemically synthesized $\mathrm{ZnO}$ NPs at concentration $400 \mathrm{mg} / \mathrm{kg}$. Values are expressed as mean $\pm \mathrm{SD}(n=4)$. Bars assigned with different superscripts are significantly different $(P<0.05)$. b Activity of superoxide dismutase (SOD) enzyme in the liver and gills in the control group and in GT1-fish fed green synthesized $\mathrm{ZnO}$ NPs at concentration $100 \mathrm{mg} / \mathrm{kg}$, CT1 - fish fed chemically synthesized ZnO NPs at concentration $100 \mathrm{mg} / \mathrm{kg}$, GT2 - fish fed green synthesized ZnO NPs at concentration $200 \mathrm{mg} / \mathrm{kg}$, CT2 - fish fed chemically synthesized ZnO NPs at concentration $200 \mathrm{mg} / \mathrm{kg}$, GT3fish fed green synthesized ZnO NPs at concentration $400 \mathrm{mg} / \mathrm{kg}$, CT3fish fed chemically synthesized ZnO NPs at concentration $400 \mathrm{mg} / \mathrm{kg}$. Values are expressed as mean $\pm \mathrm{SD}(n=4)$. Bars assigned with different superscripts are significantly different $(P<0.05)$. c Activity of glutathione peroxidase (GPx) enzyme in the liver and gills in the control group and in GT1-fish fed green synthesized ZnO NPs at concentration 100 $\mathrm{mg} / \mathrm{kg}, \mathrm{CT} 1$ - fish fed chemically synthesized ZnO NPs at concentration $100 \mathrm{mg} / \mathrm{kg}$, GT2 - fish fed green synthesized ZnO NPs at concentration $200 \mathrm{mg} / \mathrm{kg}$, CT2 - fish fed chemically synthesized ZnO NPs at

order of accumulation of zinc was liver $>$ muscle $>$ gills in fish fed both diets. Significantly higher $(P<0.05)$ accumulation of zinc was detected in all the three tissues concentration $200 \mathrm{mg} / \mathrm{kg}$, GT3 - fish fed green synthesized ZnO NPs at concentration $400 \mathrm{mg} / \mathrm{kg}$, CT3 - fish fed chemically synthesized $\mathrm{ZnO}$ $\mathrm{NPs}$ at concentration $400 \mathrm{mg} / \mathrm{kg}$. Values are expressed as mean $\pm \mathrm{SD}(n$ $=4)$. Bars assigned with different superscripts are significantly different $(P<0.05)$. d Activity of reduced glutathione (GSH) enzyme in the liver and gills in the control group and in GT1 - fish fed green synthesized $\mathrm{ZnO}$ NPs at concentration $100 \mathrm{mg} / \mathrm{kg}$, CT1 - fish fed chemically synthesized ZnO NPs at concentration $100 \mathrm{mg} / \mathrm{kg}$, GT2 - fish fed green synthesized ZnO NPs at concentration $200 \mathrm{mg} / \mathrm{kg}$, CT2 - fish fed chemically synthesized ZnO NPs at concentration $200 \mathrm{mg} / \mathrm{kg}$, GT3 - fish fed green synthesized ZnO NPs at concentration $400 \mathrm{mg} / \mathrm{kg}$, CT3 - fish fed chemically synthesized $\mathrm{ZnO}$ NPs at concentration $400 \mathrm{mg} / \mathrm{kg}$. Values are expressed as mean $\pm \operatorname{SD}(n=4)$. Bars assigned with different superscripts are significantly different $(P<0.05)$. e Activity of glutathione reductase (GR) enzyme in the liver and gills in the control group and in GT1-fish fed green synthesized $\mathrm{ZnO}$ NPs at concentration $100 \mathrm{mg} / \mathrm{kg}$, CT1 - fish fed chemically synthesized ZnO NPs at concentration $100 \mathrm{mg} / \mathrm{kg}$, GT2 fish fed green synthesized ZnO NPs at concentration $200 \mathrm{mg} / \mathrm{kg}$, CT2 fish fed chemically synthesized ZnO NPs at concentration $200 \mathrm{mg} / \mathrm{kg}$, GT3 - fish fed green synthesized ZnO NPs at concentration $400 \mathrm{mg} / \mathrm{kg}$, CT3 - fish fed chemically synthesized ZnO NPs at concentration 400 $\mathrm{mg} / \mathrm{kg}$. Values are expressed as mean $\pm \mathrm{SD}(n=4)$. Bars assigned with different superscripts are significantly different $(P<0.05)$

of fish fed CT3 and GT3 when compared with the control (Table 1). The highest $\mathrm{Zn}$ accumulation was observed in the liver at a higher dose of feed, and the mean value of 

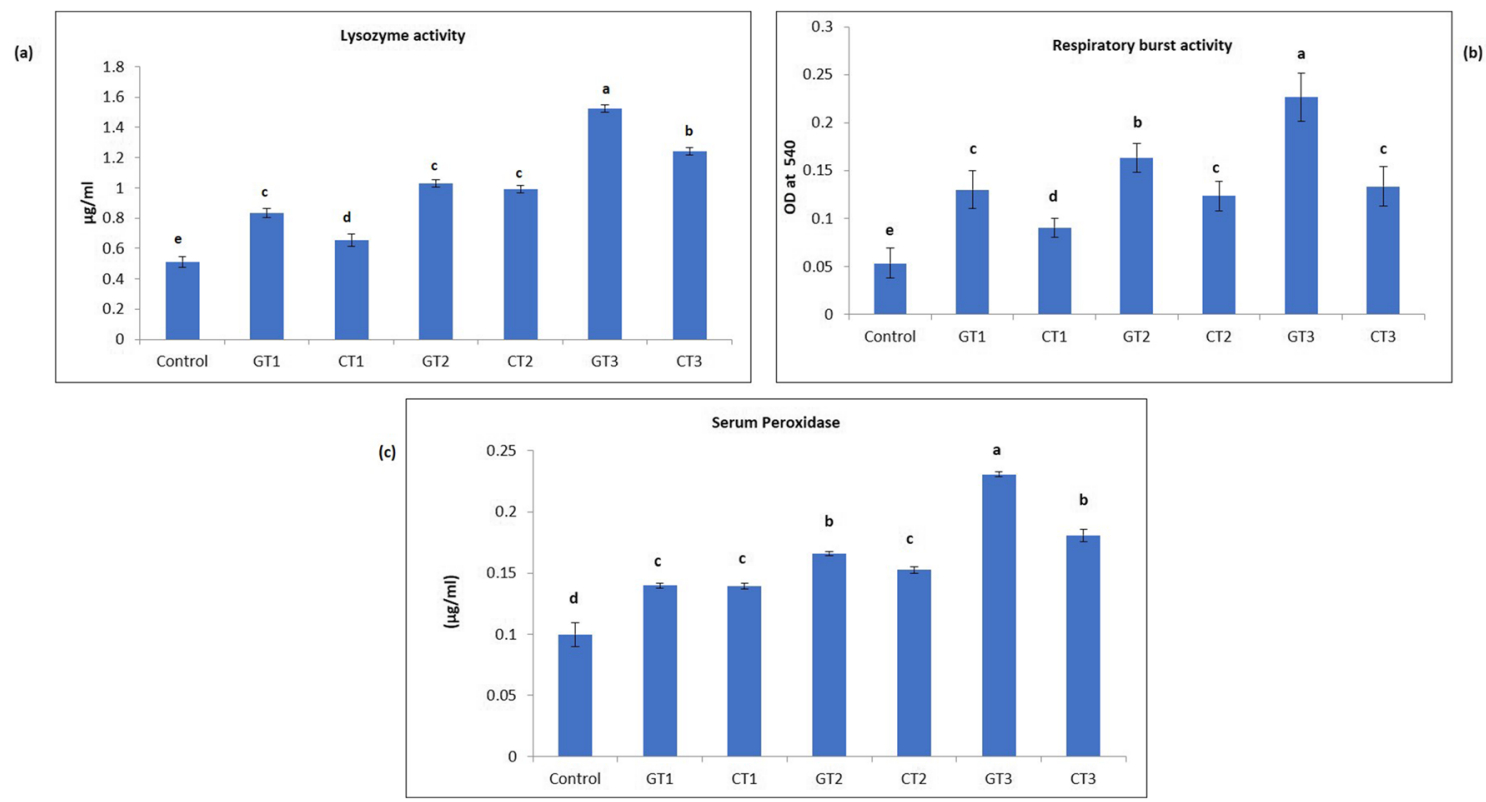

Fig. 9 a Lysozyme activity in the control group and in GT1 - group fed green synthesized ZnO NPs at concentration $100 \mathrm{mg} / \mathrm{kg}$, CT1 — group fed chemically synthesized ZnO NPs at concentration $100 \mathrm{mg} / \mathrm{kg}$, GT2group fed green synthesized ZnO NPs at concentration $200 \mathrm{mg} / \mathrm{kg}$, CT2 - group fed chemically synthesized ZnO NPs at concentration 200 $\mathrm{mg} / \mathrm{kg}$, GT3 - group fed green synthesized ZnO NPs at concentration $400 \mathrm{mg} / \mathrm{kg}$, CT3 - group fed chemically synthesized ZnO NPs at concentration $400 \mathrm{mg} / \mathrm{kg}$. Values are expressed as mean $\pm \mathrm{SD}(n=4)$. Bars assigned with different superscripts are significantly different $(P<0.05)$. b Respiratory burst activity in the control group and in GT1 - group fed green synthesized ZnO NPs at concentration $100 \mathrm{mg} / \mathrm{kg}$, CT1 - group fed chemically synthesized ZnO NPs at concentration $100 \mathrm{mg} / \mathrm{kg}$, GT2group fed green synthesized $\mathrm{ZnO} N P s$ at concentration $200 \mathrm{mg} / \mathrm{kg}$, CT2 - group fed chemically synthesized ZnO NPs at concentration 200

$\mathrm{Zn}$ in the liver was $133.17 \pm 0.37 \mathrm{ppm}$ in CT3 diet-fed fish and $113.03 \pm 0.11 \mathrm{ppm}$ in GT3 diet-fed fish. The least accumulation of $\mathrm{Zn}$ was reported in the gill tissues $57.11 \pm 0.19 \mathrm{ppm}$ in the CT3 diet-fed fish and $37.92 \pm$ $0.31 \mathrm{ppm}$ in GT3 diet-fed fish. Muscle tissues were reported to have $\mathrm{Zn}$ content less than that in the liver with $89.91 \pm 0.64 \mathrm{ppm}$ in CT3 diet-fed fish and $59.12 \pm$ $0.62 \mathrm{ppm}$ in GT3 diet-fed fish. In all the three organs tested, fish fed CT3 diet reported to have the higher $\mathrm{Zn}$ content than the fish fed GT3 diet.

\section{Determination of oxidative damage in DNA}

Results of the measurement of 8-OHdG levels suggest that DNA damage is significantly $(P<0.05)$ higher in fish fed chemically synthesized $\mathrm{ZnO} \mathrm{NP}-$ enriched feed (CT1, CT2, CT3) when compared with the control. However, the DNA damage was found to be less in the plasma of fish fed green synthesized $\mathrm{ZnO} \mathrm{NP}$ incorporated feed (Table 2). $\mathrm{mg} / \mathrm{kg}$, GT3 - group fed green synthesized ZnO NPs at concentration $400 \mathrm{mg} / \mathrm{kg}$, CT3 - group fed chemically synthesized ZnO NPs at concentration $400 \mathrm{mg} / \mathrm{kg}$. Values are expressed as mean $\pm \mathrm{SD}(n=4)$. Bars assigned with different superscripts are significantly different $(P<0.05)$. c Serum peroxidase activity the control group and in GT1 - group fed green synthesized ZnO NPs at concentration $100 \mathrm{mg} / \mathrm{kg}$, CT1 - fish fed chemically synthesized ZnO NPs at concentration $100 \mathrm{mg} / \mathrm{kg}$, GT2 - fish fed green synthesized ZnO NPs at concentration $200 \mathrm{mg} / \mathrm{kg}$, CT2 - fish fed chemically synthesized ZnO NPs at concentration $200 \mathrm{mg} / \mathrm{kg}$, GT3fish fed green synthesized ZnO NPs at concentration $400 \mathrm{mg} / \mathrm{kg}$, CT3 fish fed chemically synthesized $\mathrm{ZnO} N P s$ at concentration $400 \mathrm{mg} / \mathrm{kg}$. Values are expressed as mean $\pm \mathrm{SD}(n=4)$. Bars assigned with different superscripts are significantly different $(P<0.05)$

\section{Discussion}

The present study evaluated the possible effects of dietary $\mathrm{ZnO}$ NPs prepared by green and chemical methods on various health parameters in Nile tilapia. First, the structural properties of nanoparticles were confirmed by beginning with $\mathrm{Uv}-\mathrm{V}$ is spectrum analysis. UV-Vis spectrum of chemically synthesized and green synthesized ZnO NPs are shown in Fig. 1. Due to the surface plasmon absorbance of $\mathrm{ZnO}$ NPs, absorption peaks were observed at $360 \mathrm{~nm}$ for chemically synthesized $\mathrm{ZnO}$ NPs and $350 \mathrm{~nm}$ for green synthesized ZnO NPs which confirmed the formation of zinc oxide nanoparticles. Similar results have been documented by Jayarambabu et al. (2017) and Chaudhuri and Malodia (2017). Various Bragg's reflection peaks were revealed in the XRD spectrum and the absence of a considerable shift in the diffraction peaks of chemical and green synthesized $\mathrm{ZnO}$ NPs indicate the absence of crystalline impurities, the results of which correlates with the previously reported findings, where Jamdagni et al. 
(a)

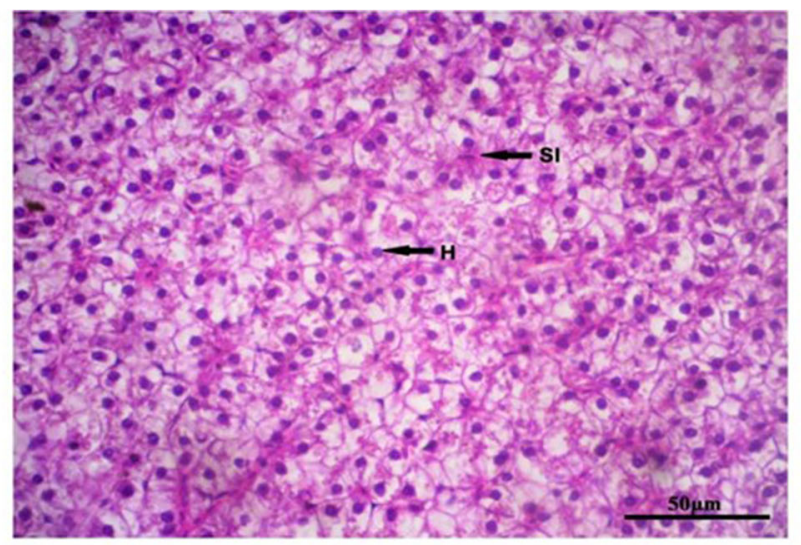

(c)

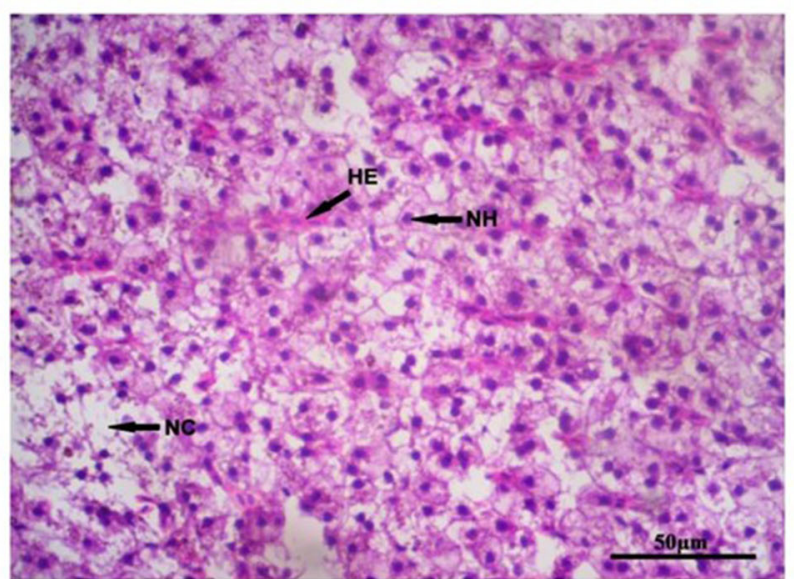

(e)

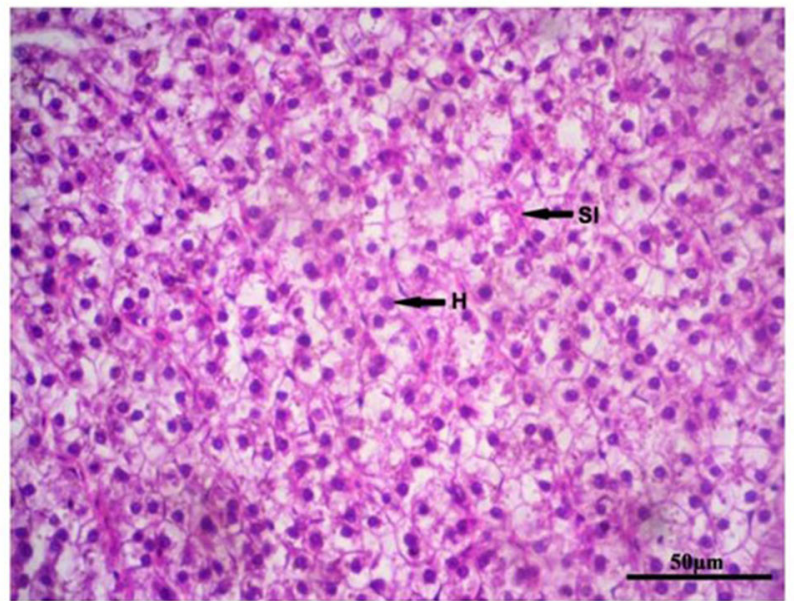

Fig. 10 a Histology of liver section of Nile tilapia in the control group showing normal architectural arrangement with abundant hepatocytes $(\mathrm{H})$ with prominent nucleus and sinusoids (SI). b Histology of gill section of Nile tilapia in the control group showing secondary gill lamellae (SGL), primary gill lamella (PGL), a single layer of epithelial cells supported by the pillar cells (PC). c Histology of liver section of Nile tilapia in the group fed chemically synthesized $\mathrm{ZnO} \mathrm{NP}$-enriched diet showing hepatocytes with moderate necrosis $(\mathrm{NH})$, some area showing amorphous aggregates of necrotic material (NC) and moderate congestion in blood

(2018) synthesized zinc oxide nanoparticles using flower extract of Nyctanthes arbortristis whereas, Mahendiran et al. (2017) compared $\mathrm{ZnO}$ NPs synthesized using Aloe vera and Hibiscus sabdariffa with the chemical method.

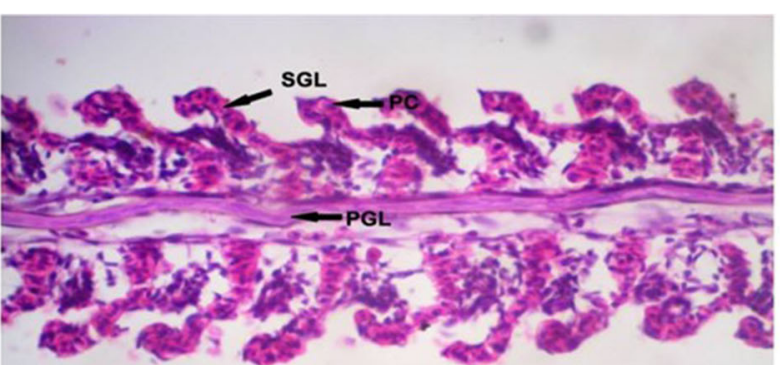

(b)
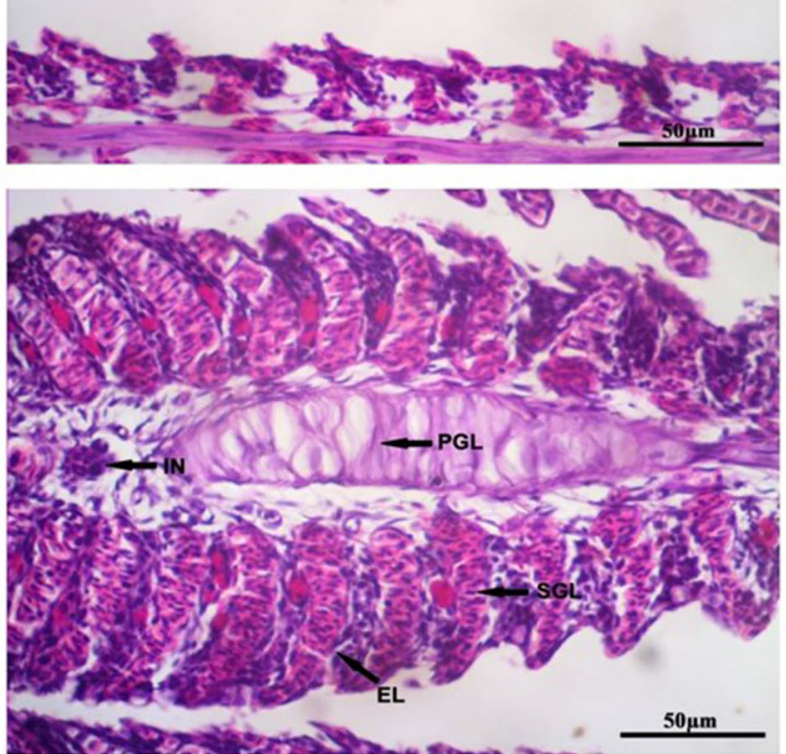

(d)

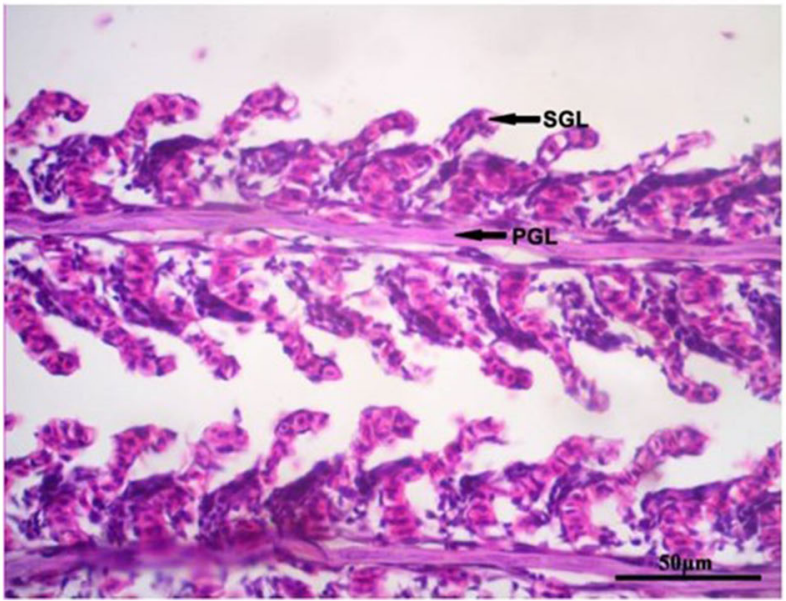

(f)

sinusoids (HE). d Histology of gill section of Nile tilapia in the group fed chemically synthesized ZnO NP-enriched diet showing moderate epithelial hyperplasia, epithelial lifting (EL) and inflammation (IN). e Histology of liver section of Nile tilapia in the group fed green synthesized $\mathrm{ZnO}$ $\mathrm{NP}$-enriched diet showing normal histology with abundant hepatocytes $(\mathrm{H})$ with prominent nucleus and sinusoids (SI). f Histology of gill section of Nile tilapia in the group fed green synthesized $\mathrm{ZnO} \mathrm{NP}$-enriched diet showing normal histology with secondary gill lamellae (SGL) and primary gill lamella (PGL)

Next was FTIR analysis that was performed to determine the functional groups responsible for capping and stabilization of ZnO NPs in the extract of $L$. aspera and oxy-cyclodextrin complex. Alcohols, phenols and various other phytochemicals 
Table $1 \mathrm{Zn}(\mathrm{ppm})$ accumulation from ZnO NPs in the liver, gills and muscles of Nile tilapia. Values are expressed as mean $\pm \operatorname{SD}(n=4)$. Values in a row with different superscripts are significantly different $(P<0.05)$

\begin{tabular}{llll}
\hline Tissues & $\begin{array}{l}\text { Control-Zn content } \\
\text { (ppm/g tissue) }\end{array}$ & $\begin{array}{l}\text { CT3 NP-Zn content } \\
\text { (ppm/g tissue) }\end{array}$ & $\begin{array}{l}\text { GT3 NP-Zn content } \\
\text { (ppm/g tissue) }\end{array}$ \\
\hline Liver & $0.152 \pm 0.001^{\mathrm{c}}$ & $133.17 \pm 0.37^{\mathrm{a}}$ & $113.03 \pm 0.11^{\mathrm{b}}$ \\
Gills & $0.053 \pm 0.001^{\mathrm{c}}$ & $57.11 \pm 0.19^{\mathrm{a}}$ & $37.92 \pm 0.31^{\mathrm{b}}$ \\
Muscle & $0.043 \pm 0.001^{\mathrm{c}}$ & $89.91 \pm 0.64^{\mathrm{a}}$ & $59.12 \pm 0.62^{\mathrm{b}}$ \\
\hline
\end{tabular}

in L. aspera interact with the zinc surface and help in the stabilization of $\mathrm{ZnO}$ NPs. Our results match with the already reported results where $\mathrm{ZnO} N$ Ps were green synthesized using extracts of Calotropis gigantea and Laurus nobilis (Chaudhuri and Malodia 2017; Fakhari et al. 2019). Zeta potential values of both nanoparticles indicate that they are stable which is due to the electrostatic repulsive force.

Before proceeding to feed preparation, the in vitro antioxidant activity measured by DPPH and reducing power assay revealed that green synthesized $\mathrm{ZnO}$ NP solution exhibit higher antioxidant property than chemically synthesized $\mathrm{ZnO}$ NPs. However, none of the nanoparticles could exceed the antioxidant property of the standard ascorbic acid in both assays. This result is similar to the already reported result by Safawo et al. (2018).

This was followed by the antibacterial property of nanoparticle solutions and the results of antibacterial activity of $\mathrm{ZnO}$ NPs reported that green synthesized $\mathrm{ZnO}$ NPs revealed enhanced activity against $A$. hydrophila and $S$. agalactiaea. Previous studies have also confirmed that $\mathrm{ZnO}$ NPs exhibits strong antibacterial activity against gram-positive and gramnegative bacteria, also the green synthesized ZnO NPs are reported to have better activity than chemically synthesized ZnO NPs (Vimala et al. 2014; Venkatachalam et al. 2016; Hazra et al. 2013). The possible mechanism of antibacterial activity by $\mathrm{ZnO}$ NPs are due to the loss of bacterial cell integrity when $\mathrm{ZnO}$ NPs come in direct contact with the cell wall (Zhang et al. 2007), releasing $\mathrm{Zn}^{2+}$ ions that are antimicrobial (Li et al. 2011) and formation of reactive oxygen species (ROS) (Jalal et al. 2010).

Earlier reports have confirmed the involvement of nanoparticles in generating oxidative stress by either inhibiting the antioxidant system of cells (Marisa et al. 2016) or by the production of ROS (Vale et al. 2016) thus inducing a toxic effect. Superoxide dismutase (SOD) and catalase (CAT) are tissue-specific biomarker enzymes that act together to form a first line of defence against oxidative stress where SOD catalyses the transformation of superoxide radical to hydrogen peroxide and CAT catalyses hydrogen peroxide to water and oxygen (Ruas et al. 2008; Cao et al. 2012). When comparing CAT activity in the liver and gills, our results reported a significant increase in CAT activity in the liver and gills of fish fed green synthesized nanoparticle at all concentrations, whereas all other diets enriched with chemically synthesized $\mathrm{ZnO} \mathrm{NP}$ (CT1, CT2 and CT3) resulted in significant reduction in the activity of CAT in both the liver and gills. Thus, at a higher concentration of green synthesized $\mathrm{ZnO} \mathrm{NP}$-enriched feed (GT3), an increase in the antioxidant defence was noticed, which could be due to the increased production of oxygen free radical that boosts the antioxidant activities thus helping the cells to protect from free radical injury (Torres et al. 2002). Similar results were reported in SOD activity in the liver and gills. A previous study has confirmed that more than any other enzyme, the activity of SOD would be affected in the liver, gills and intestine when exposed to nanoparticles (Hao et al. 2009). The increase in CAT activity would be due to the removal of hydrogen peroxide radicals reduced by SOD. The activity of GPx was observed to be significantly higher in the liver and gills of fish fed GT1, GT2 and GT3 diets in a concentration-dependent manner. The rest of the diets exhibited a significant reduction in GPx activity in the liver and gills. The reduction in GPx activity in fish fed with $\mathrm{ZnO}$ nanofeed either indicates its decreased potential in breaking hydrogen peroxide or an overproduction of hydrogen peroxide or may be as a result of the action of heavy metals directly on the synthesis of the enzyme. Glutathione peroxidase (GPx) is involved in the detoxification of hydroperoxides where they catalyse the reduction of hydrogen peroxide to water in which reduced glutathione (GSH) acts as the source of hydrogen and gets converted to the oxidized form (Alkaladi

Table 2 Plasma 8-OHdG levels in Nile tilapia. Values are expressed as mean $\pm \operatorname{SD}(n=4)$. Values in a row with different superscripts are significantly different $(P<0.05)$

\begin{tabular}{lllllllll}
\hline & Control & CT1 & CT2 & CT3 & Control & GT1 & GT2 & GT3 \\
\hline Plasma 8-OHdG levels (ng/ml) & $2.9 \pm 0.006^{\mathrm{d}}$ & $3.2 \pm 0.002^{\mathrm{c}}$ & $3.5 \pm 0.003^{\mathrm{b}}$ & $3.89 \pm 0.008^{\mathrm{a}}$ & $2.90 \pm 0.003^{\mathrm{a}}$ & $2.64 \pm 0.008^{\mathrm{b}}$ & $2.35 \pm 0.002^{\mathrm{c}}$ & $1.99 \pm 0.003^{\mathrm{d}}$ \\
\hline
\end{tabular}


2018). The activity of the GSH enzyme was reported to be significantly declined in the liver and gills of fish fed diets enriched with chemically synthesized $\mathrm{ZnO}$ nanopowder. On the other hand, all diets incorporated with green synthesized $\mathrm{ZnO}$ nanopowder (GT1, GT2 and GT3) displayed a significant increase in the activity of glutathione reductase (GR) enzyme level in the gills. None of the diets enriched with chemically synthesized $\mathrm{ZnO}$ nanopowder could augment the GR activity in the liver and gills. Our results coincide with results already reported, which proved that ZnO NPs inhibited SOD, CAT and GPx activities in juvenile carp (Hao and Chen 2012), and in Nile tilapia where SOD, CAT, GPx, GSH and GR activities were declined (Abdelazim et al. 2018).

Lysozyme, a cationic enzyme that helps in lysing the $\beta-1,4$ glycosidic bonds in the peptidoglycan layer present in the cell wall of the bacterium is considered an important ecotoxicological biomarker in fish (Whyte 2007). Our results report that lysozyme activity in Nile tilapia was increased significantly $(P$ $<0.05)$ in a concentration-dependent manner when fish were fed green synthesized $\mathrm{ZnO} \mathrm{NP}$ enriched feed and chemically synthesized $\mathrm{ZnO} \mathrm{NP}$ feed with the maximum lysozyme activity detected in fish that were fed GT3 diet. This suggests that the neutrophils were stimulated to release lysozyme in the presence of nanoparticles. Similarly, dietary zinc oxide and selenium nanoparticle feed were revealed to enhance the lysozyme activity in Labeo rohita (Swain et al. 2018), $\beta-1,3$ glucan binding protein-based zinc oxide nanoparticle elevated lysozyme activity (Anjugam et al. 2018) which are in line with the present investigation. Only a few studies have been reported so far that determined the lysozyme activity in fish after treating it with nanoparticles. Their results reported diminished activity after 25 days when Epinephelus coioides was exposed to copper NPs and copper sulfphate NPs $\left(\mathrm{CuSO}_{4}\right)$ (Wang et al. 2015), in O. niloticus after 60 days of exposure to iron oxide nanoparticle (Ates et al. 2016). Another study revealed decreased lysozyme activity in the serum for large $\mathrm{ZnO}$ NPs at the lowest concentration on the 14th day (Kaya et al. 2016). Production of oxidative radicals, peroxidase and activation of neutrophils account for the non-specific defence mechanism in fish as oxidative burst or respiratory burst; different cells release reactive oxygen species that are noxious for bacterial pathogens (Semple et al. 2018). In the present study, fishes in all treatment groups exhibited a significantly higher $(P<0.05)$ respiratory burst activity in a concentrationdependent manner when compared with the control, with the maximum activity in the fish that were fed GT3 diet indicating the role of nanoparticle in promoting the activity of macrophages and neutrophils. Myeloperoxidase enzyme exists in the granules of polymorphonuclear neutrophils, macrophage and monocytes of fish. In the present study, serum peroxidase activity was observed to be significantly higher $(P<0.05)$ in all treatment groups when compared with the control with the maximum activity in the serum of fish fed GT3. The results suggest that zinc oxide nanoparticles increased the activity of polymorphonuclear cells.

Cellular changes in the organs due to nanoparticles can be evaluated by histopathology (Shobana et al. 2018). Histological changes were observed in the gills and liver of fish fed chemically synthesized $\mathrm{ZnO} \mathrm{NP}$-enriched feed, whereas these organs in the fish fed green synthesized $\mathrm{ZnO}$ NP incorporated feed did not show any pathological alterations just like the control sections. This is attributed to the presence of $L$. aspera extract and oxy-cyclodextrin present in the green synthesized nanopowder. Liver section of fish fed diet with chemically synthesized $\mathrm{ZnO}$ NP was observed to have moderate necrosis, aggregates of necrotic material also and moderate congestion in blood sinusoids. The liver helps in the detoxification of toxic metabolites, which results in the accumulation of these chemicals in the liver. Evidence from earlier studies where similar alterations in the liver of O. mossambicus exposed to ZnO NPs (Shahzad et al. 2018) and exposure to small and large size ZnO NPs for 14 days in the liver of $O$. niloticus (Kaya et al. 2016) support the result of the present study.

Gills are associated with respiratory and osmoregulatory function in fish, hence damage to gills can severely affect these functions and can result in stress (Saber 2011). In the present study, gills of fish fed chemically synthesized $\mathrm{ZnO} \mathrm{NP}$ feed were observed to have inflammation, epithelial hyperplasia and epithelial lifting. These pathological changes in the gills can help the toxic compounds to have close contact with the vascular system of fish affecting its respiration and eventually the health (Krishnaraj et al. 2016). The results of the present study are supported by the results of gill histopathology in Cyprinus carpio exposed to $\mathrm{ZnO} \mathrm{NP}$ for 10 days (Subashkumar and Selvanayagam 2014). Similarly, aberrations in the gill structure were also observed in O. mossambicus exposed to $\mathrm{ZnO}$ NP after 14 days (Suganthi et al. 2015).

In the present study, accumulation of $\mathrm{Zn}$ varied depending on the type of tissue. The tissue that possessed the most $\mathrm{Zn}$ content was the liver of fish fed CT3 and GT3 diet, followed by the muscle and gills. The liver plays the role of chemical assimilation of metals that have entered the body, eventually helping in detoxification (Shahzad et al. 2018). Since the mode of exposure was through diet, $\mathrm{Zn}$ that was ingested must have accumulated in the liver. Also, the liver being the site of zinc metabolism has an affinity towards zinc due to the expression of metallothionein, a zinc-binding protein. This results in lesser accumulation of zinc in other organs (Giardina et al. 2009). Results of the present study reported the least $\mathrm{Zn}$ content in the gills. Gills help in ion exchange, gas transport and respiratory function (Saber 2011). The gills can be considered the first target organ for toxicants as the gill epithelia are the first to come in contact with the chemicals. Accumulation on gills could be due to the adsorption of $\mathrm{Zn}$ 
in the feed when the feed comes in contact with the water (Hao et al. 2013). Also, the Zn-calcium transport carrier in the gill epithelium helps in the uptake of zinc from water (Giardina et al. 2009). In fish muscle, metal accumulation is usually limited. But in the present study, the tissue with the most $\mathrm{Zn}$ content after the liver was the muscle tissue. Even though muscles are not a significant target, in this study, muscles were chosen since it is the edible tissue. Previous studies reported the highest $\mathrm{Zn}$ accumulation in the liver of $O$. mossambicus (Shahzad et al. 2018) and in the intestine of O. niloticus followed by the liver, gills and muscle (Kaya et al. 2015).

8 -Hydroxy-2'-deoxyguanosine $(8-\mathrm{OHdG})$ that is derived from hydroxyl radical attack of deoxyguanosine residues has been widely considered a biomarker of oxidative damage to DNA (Singh et al. 1988). The presence of residual 8-OHdG in DNA results in GC to TA transversion unless repaired prior to DNA replication (Cheng et al. 1992). Formation of 8-OHdG, an oxidatively damaged DNA product, is reported to be accelerated by oxygen radical-producing agents; however, antioxidants and flavonoids help reduce 8-OHdG levels (Oliveira et al. 2010). As mentioned earlier, accumulation of 8-OHdG is promoted by various free radical-producing agents by hydroxylation of deoxyguanosine residues in DNA. Mispairing of damaged guanine is formed due to DNA glycosylase enzyme and is removed as 8-OHdG (Obulesu and Rao 2010). It is assumed that the bioactive compounds present in L. aspera and oxy-cyclodextrin helped reduce the factors that form free radicals and may have protected the fish immune system.

Nanoparticles are usually synthesized by conventional methods such as physical and chemical methods and also by the green approach. Conventional methods of nanoparticle synthesis use toxic chemicals, synthetic additives and nonpolar solvents which are not safe and eco-friendly. On the other hand, green synthesis of nanoparticles involves bacteria, fungi or plants with antioxidant or reducing properties to develop the desired nanoparticles. This is an eco-friendly approach to synthesize nanoparticles. Among the nanoparticles, $\mathrm{ZnO}$ NPs have gained popularity being a versatile semiconductor with excellent stability. However, minimal information is available on the application of $\mathrm{ZnO} \mathrm{NP}$ in aquaculture. There is no information on the comparative effect of $\mathrm{ZnO}$ NPs synthesized by the chemical method and by the green approach on the overall health status of fish. This study aimed at analysing the possible toxic effect and changes in the health of Nile tilapia by feeding diets incorporated with chemically synthesized and green synthesized $\mathrm{ZnO}$ NP. The various phytochemicals in the L. aspera extract acted as capping and stabilizing agent in the green synthesis, whereas the oxy-CD complex has encapsulation efficiency with antioxidant property. The combined action of these two plant-based extracts might have improved the antioxidant ability of green synthesized $\mathrm{ZnO}$ NP. This was proven to be true when the present study compared the changes induced by both types of NP through dietary administration in Nile tilapia. There is great importance for this study. To the best of our knowledge, this is the first record about the comparative effects of dietary nanozinc that was prepared by the green method and conventional chemical method in Nile tilapia. In short, the observations from this study conclude that green synthesized $\mathrm{ZnO}$ NPs prepared by combining two plant-derived extracts at the highest dose $(400 \mathrm{mg} / \mathrm{kg})$ in the diet can ameliorate the activity of antioxidant enzymes thereby reducing oxidative stress to an extent and improving the immune status without inducing any histological alterations in the organs of fish. Further studies to analyse the transcriptomic profile changes and extensive field trials are needed to improve our understanding of the benefits of nanozinc feed further.

Acknowledgements Amitha Kurian is thankful for the KUFOS PhD fellowship provided by the School of Ocean Science and Technology, Kerala University of Fisheries and Ocean Studies (KUFOS), Kochi, Kerala, India, for completing this study. The authors extend their gratitude to Dr. Anbazhagan, Senior Assistant Professor, Department of Chemistry, SASTRA University, Thanjavur, Tamil Nadu, India, for assisting in Biophysical Characterization studies, Professor Sreedharan, Aasha Biochem, Kozhikode, Kerala, India, for his help with oxycyclodextrin studies.

Authors' contributions AK was involved in the concept design, data analysis and execution of this project. PE was involved in the corrections in the work plan of this study, improvement of the manuscript by critical reviewing and finalization of the manuscript. All authors read and approved the final manuscript.

Funding Not applicable.

Data Availability The datasets used and/or analysed during the current study are available from the corresponding author on reasonable request.

\section{Compliance with ethical standards}

Competing interests The authors declare that they have no competing interests

Ethics approval and consent to participate Proceedings

KUFOS, Panangad, Kochi, Kerala - Committee to review the $\mathrm{PhD}$ work proposal for Ms. Amitha - PhD thesis work - constituted - Orders issued.

General Administration No. SOST/PhD001/2019 Date: 30.03.2017 Panagad, Kochi

ORDER

1. Dr. E.P Preetham presented a proposal on "Evaluation of costeffective feed additives as dietary supplement to improve growth, immune function, antioxidant activity and disease resistance in Nile tilapia (Oreochromis niloticus)" and detailed experiments using fish. The project is done by Amitha Kurian for her PhD thesis work (Details of works enclosed).

2. The members discussed the matter and instructed Dr. E.P. Preetham to stick on to the rules and regulations framed by the animal ethics 
committee of Indian Council of Agricultural Research (ICAR) or Indian Council of Medical Research (ICMR).

3. Dr. E.P Preetham agreed to stick to the rules and regulations framed by the committee and also emphasized that the collaborating institutions also have animal ethical clearance.

4. The committee approved the project work and authorized Prof. Dr. Suresh Kumar, Director, School of Ocean Studies and Technology, to monitor the activity and report to the committee.

\section{Members}

1. Dr. Suresh Kumar (Chairman, PhD Committee; Director, SOST)

2. Dr. Prabhakaran (Advisor, $\mathrm{PhD}$ Committee)

3. Dr. Joseph (External member)

4. Dr. E.P Preetham (PhD Supervisor)

\section{A. The methodology involving fish blood collection is performed as the following:}

\section{Serum collection (Doan et al. 2016)}

Fish are anaesthetized with clove oil $\left(5 \mathrm{ml} \mathrm{L}^{-1}\right)$, followed by blood collection from the caudal vein with a $1 \mathrm{ml}$ plastic syringe sprayed with heparin and stored at $4{ }^{\circ} \mathrm{C}$ until the next day. Using a 1-ml syringe, blood is collected from the caudal vein. The collected blood samples are immediately transferred into Eppendorf tubes and are allowed to clot for $1 \mathrm{~h}$ at room temperature and $4 \mathrm{~h}$ at $4{ }^{\circ} \mathrm{C}$. The samples are centrifuged at $1500 \times \mathrm{g}$, for $5 \mathrm{~min}$, at $4{ }^{\circ} \mathrm{C}$ in a cooling centrifuge. The serum is finally collected and stored at $-20^{\circ} \mathrm{C}$ until assay.

\section{Consent for publication Not applicable.}

Open Access This article is licensed under a Creative Commons Attribution 4.0 International License, which permits use, sharing, adaptation, distribution and reproduction in any medium or format, as long as you give appropriate credit to the original author(s) and the source, provide a link to the Creative Commons licence, and indicate if changes were made. The images or other third party material in this article are included in the article's Creative Commons licence, unless indicated otherwise in a credit line to the material. If material is not included in the article's Creative Commons licence and your intended use is not permitted by statutory regulation or exceeds the permitted use, you will need to obtain permission directly from the copyright holder. To view a copy of this licence, visit http://creativecommons.org/licenses/by/4.0/.

\section{References}

Abarike ED, Jian J, Tang J, Cai J, Yu H, Lihua C, Jun L (2019) Influence of traditional Chinese medicine and Bacillus species (TCMBS) on growth, immune response and disease resistance in Nile tilapia, Oreochromis niloticus. Fish Shellfish Immunol 91:417. https://doi. org/10.1016/j.fsi.2019.04.146

Abdelazim AM, Saadeldin IM, Swelum AA-A, Afifi MM, Alkaladi A (2018) Oxidative stress in the muscles of the fish Nile tilapia Caused by zinc oxide nanoparticles and its modulation by vitamins $\mathrm{C}$ and $\mathrm{E}$. Oxidative Med Cell Longev 2018:1-9. https://doi.org/10.1155/ 2018/6926712

Aebi H (1974) Catalase. In: Bergmeyer HV (ed) Methods in enzymatic analysis. Academic Press, New York, pp 674-684

Alkaladi A (2018) Vitamins E and C ameliorate the oxidative stresses induced by zinc oxide nanoparticles on liver and gills of
Oreochromis niloticus. Saudi J Biol Sci 26:357-362. https://doi. org/10.1016/j.sjbs.2018.07.001

Amornpitoksuk P, Suwanboon S, Sangkanu S, Sukhoom A, Wudtipan J, Srijan K, Kaewtaro S (2011) Synthesis, photocatalytic and antibacterial activities of $\mathrm{ZnO}$ particles modified by diblock copolymer. Powder Technol 212:432-438. https://doi.org/10.1016/j.powtec. 2011.06.028

Anderson DP, Siwicki AK (1995) Basic hematology and serology for fish health programs. In: Shariff M, Auther JR, Subasinghe RP (eds) Diseases in Asian Aquaculture II. Fish Health Section, Asian Fisheries Society, Manila, pp 185-202

Anjugam M, Vaseeharan B, Iswarya A, Gobi N, Divya M, Thangaraj MP, Elumalai P (2018) Effect of $\beta-1,3$ glucan binding protein based zinc oxide nanoparticles supplemented diet on immune response and disease resistance in Oreochromis mossambicus against Aeromonas hydrophila. Fish Shellfish Immunol 76:247-259. https://doi.org/10.1016/j.fsi.2018.03.012

Anu PR, Jayachandran PR, Sreekumar PK, Bijoy Nandan S (2014) A review on heavy metal pollution in Cochin Backwaters, Southwest Coast of India. Int J Mar Sci 10:92-98

Ates M, Demir V, Arslan Z, Kaya H, Y1lmaz S, Camas M (2016) Chronic exposure of tilapia (Oreochromis niloticus) to iron oxide nanoparticles: effects of particle morphology on accumulation, elimination, hematology and immune responses. Aquat Toxicol 177:22-32. https://doi.org/10.1016/j.aquatox.2016.05.005

Bauer AW, Kirby WMM, Sherris JC, Turck M (1966) Antibiotic Susceptibility Testing by a Standardized Single Disk Method. Am J Clin Pathol 45:493-496. https://doi.org/10.1093/ajcp/45.4 ts.493

Bhattacharya R, Mukherjee P (2008) Biological properties of "naked" metal nanoparticles. Adv Drug Deliv Rev 60:1289-1306. https:// doi.org/10.1016/j.addr.2008.03.013

Boyne AF, Ellman GL (1972) A methodology for analysis of tissue sulfhydryl components. Anal Biochem 46:639-653. https://doi. org/10.1016/0003-2697(72)90335-1

Cao LL, Huang W, Shan X, Ye Z, Dou S (2012) Tissue-specific accumulation of cadmium and its effects on antioxidative responses in Japanese flounder juveniles. Environ Toxicol Pharmacol 33:16-25. https://doi.org/10.1016/j.etap.2011.10.003

Chaudhuri SK, Malodia L (2017) Biosynthesis of zinc oxide nanoparticles using leaf extract of Calotropis gigantea: characterization and its evaluation on tree seedling growth in nursery stage. Appl Nanosci 7: 501-512. https://doi.org/10.1007/s13204-017-0586-7

Cheng KC, Cahill DS, Kasai H, Nishimura S, Loeb LA (1992) 8Hydroxyguanine, an abundant form of oxidative DNA damage, causes G-T and A-C substitutions. J Biol Chem 267:166-172. https://doi.org/10.1007/978-3-0348-7337-6 9

Connolly M, Fernández M, Conde E, Torrent F, Navas JM, FernándezCruz ML (2016) Tissue distribution of zinc and subtle oxidative stress effects after dietary administration of $\mathrm{ZnO}$ nanoparticles to rainbow trout. Sci Total Environ 551-552:334-343. https://doi.org/ 10.1016/j.scitotenv.2016.01.186

Das D, Nath BC, Phukon P, Kalita A, Dolui SK (2013) Synthesis of ZnO nanoparticles and evaluation of antioxidant and cytotoxic activity. Colloids Surf B: Biointerfaces 111:556-560. https://doi.org/10. 1016/j.colsurfb.2013.06.041

Doan HV, Hoseinifar SH, Tapingkae W, Tongsiri S, Khamtavee P (2016) Combined administration of low molecular weight sodium alginate boosted immunomodulatory, disease resistance and growth enhancing effects of Lactobacillus plantarum in Nile tilapia (Oreochromis niloticus). Fish Shellfish Immunol 58:678-685. https://doi.org/10. 1016/j.fsi.2016.10.013

Fakhari S, Jamzad M, Fard HK (2019) Green synthesis of zinc oxide nanoparticles: a comparison. Green Chem Lett Rev 12:19-24. https://doi.org/10.1080/17518253.2018.1547925

Giardina A, Larson SF, Wisner B, Wheeler J, Chao M (2009) Long-term and acute effects of zinc contamination of a stream on fish mortality 
and physiology. Environ Toxicol Chem 28:287-295. https://doi.org/ 10.1897/07-461.1

Goldberg DM, Spooner RJ (1983) Glutathione reductase (third ed.) J. Bergmeyer, M. GraBl, H.U.Bergmeyer (Eds.), Methods of enzymatic analysis, vol. 111, Verlag Chemie, Weinheim 258-265.

Hafeman DG, Sunde RA, Hoekstra WG (1974) Effect of dietary selenium on erythrocyte and liver glutathione peroxidase in the rat. J Nutr 104:580-587. https://doi.org/10.1093/jn/104.5.580

Hao L, Chen L (2012) Oxidative stress responses in different organs of carp (Cyprinus carpio) with exposure to $\mathrm{ZnO}$ nanoparticles. Ecotoxicol Environ Saf 80:103-110. https://doi.org/10.1016/j. ecoenv.2012.02.017

Hao L, Wang Z, Xing B (2009) Effect of sub-acute exposure to TiO2 nanoparticles on oxidative stress and histopathological changes in Juvenile Carp (Cyprinus carpio). J Environ Sci 21:1459-1466. https://doi.org/10.1016/s10010742(08)62440-7

Hao L, Chen L, Hao J, Zhong N (2013) Bioaccumulation and sub-acute toxicity of zinc oxide nanoparticles in juvenile carp (Cyprinus carpio): a comparative study with its bulk counterparts. Ecotoxicol Environ Saf 91:52-60

Hazra C, Kundu D, Chaudhari A, Jana T (2013) Biogenic synthesis, characterization, toxicity and photocatalysis of zinc sulfide nanoparticles using rhamnolipids from Pseudomonas aeruginosaBS01 as capping and stabilizing agent. J Chem Technol Biotechnol 88: 1039-1048. https://doi.org/10.1002/jctb.3934

Humason GL (1979) Animal tissue techniques, 4th edn. WH Freeman and Company, San Francisco, USA, pp 3-331

Jalal R, Goharshadi EK, Abareshi M, Moosavi M, Yousefi A, Nancarrow P (2010) ZnO nanofluids: Green synthesis, characterization, and antibacterial activity. Mater Chem Phys 121:198-201. https://doi. org/10.1016/j.matchemphys.2010.01.020

Jamdagni P, Khatri P, Rana J (2018) Green synthesis of zinc oxide nanoparticles using flower extract of Nyctanthes arbor-tristis and their antifungal activity. Journal of King Saud University - Science 30: 168-175. https://doi.org/10.1016/j.jksus.2016.10.002

Jayarambabu N, Sivakumari B, Prabhu YT (2017) Germination and growth characteristics of mungbean seeds affected by synthesized zinc oxide nanoparticles. International Journal of Current Engineering and Technology 5:3411-3416

Kaya H, Aydın F, Gürkan M, Yılmaz S, Ates M, Demir V, Arslan Z (2015) Effects of zinc oxide nanoparticles on bioaccumulation and oxidative stress in different organs of tilapia (Oreochromis niloticus). Environ Toxicol Pharmacol 40:936-947. https://doi.org/ 10.1016/j.etap.2015.10.001

Kaya H, Aydın F, Gürkan M, Yılmaz S, Ates M, Demir V, Arslan Z (2016) A comparative toxicity study between small and large size zinc oxide nanoparticles in tilapia (Oreochromis niloticus): Organ pathologies, osmoregulatory responses and immunological parameters. Chemosphere 144:571-582. https://doi.org/10.1016/j. chemosphere.2015.09.024

Krishnaraj C, Harper SL, Yun S-I (2016) In Vivo toxicological assessment of biologically synthesized silver nanoparticles in adult Zebrafish (Danio rerio). J Hazard Mater 301:480-491. https://doi. org/10.1016/j.jhazmat.2015.09.022

Kumar R, Sharon M, Choudhary AK (2010) Nanotechnology in agricultural diseases and food safety Journal of Phytology 83-92.

Kurian A, Van Doan H, Tapingkae W, Elumalai P (2019) Modulation of mucosal parameters, innate immunity, growth and resistance against Streptococcus agalactiae by enrichment of Nile tilapia (Oreochromis niloticus) diet with Leucas aspera. Fish Shellfish Immunol 97:165172

Li J, Guo D, Wang X, Wang H, Jiang H, Chen B (2010) The photodynamic effect of different size $\mathrm{ZnO}$ nanoparticles on cancer cell proliferation in vitro. Nanoscale Res Lett 5:1063-1071. https://doi.org/ 10.1007/s11671-010-9603-4
Li M, Zhu L, Lin D (2011) Toxicity of ZnO nanoparticles toEscherichia coli: mechanism and the influence of medium components. Environ Sci Technol 45:1977-1983. https://doi.org/10.1021/es102624t

Lowry OH, Rosebrough NJ, Farr AL, Randall RJ (1951) Protein measurements with the folin phenol reagent. J Biol Chem 193:265-275

Mahendiran D, Subash G, Selvan DA, Rehana D, Kumar RS, Rahiman AK (2017) Biosynthesis of zinc oxide nanoparticles using plant extracts of Aloe vera and Hibiscus sabdariffa: phytochemical, antibacterial, antioxidant and anti-proliferative studies. BioNanoScience 7:530-545. https://doi.org/10.1007/s12668-017-0418-y

Marisa I, Matozzo V, Munari M, Binelli A, Parolini M, Martucci A, Franceschinis E, Brianese N, Marin MG (2016) In vivo exposure of the marine clam Ruditapes philippinarum to zinc oxide nanoparticles: responses in gills, digestive gland and haemolymph. Environ Sci Pollut Res 23:15275-15293. https://doi.org/10.1007/s11356016-6690-5

Musthafa MS, Asgari SM, Kurian A, Elumalai P, Jawahar Ali AR, Paray BA, Al-Sadoon MK (2018) Protective efficacy of Mucuna pruriens (L.) seed meal-enriched diet on growth performance, innate immunity, and disease resistance in Oreochromis mossambicus against Aeromonas hydrophila. Fish Shellfish Immunol 75:374-380

Nasapon P, Ampai P, Maitree S, Leelapornpisid P (2010) Antiglycation and antioxidant activities of oxyresveratrol extracted from the heartwood of Artocarpus lakoocha Roxb. Maejo International Journal of Science and Technology 4:454-461

Obulesu M, Rao DM (2010) DNA damage and impairment of DNA repair in Alzheimer's disease. Int J Neurosci 120:397-403

Oliveira M, Ahmad I, Maria VL, Ferreira CS, Serafim A, Bebianno MJ, Pacheco M, Santos MA (2010) Evaluation of oxidative DNA lesions in plasma and nuclear abnormalities in erythrocytes of wild fish (Liza aurata) as an integrated approach to genotoxicity assessment. Mutat Res 703:83-89

Oyaizu M (1986) Studies on products of browning reaction. Antioxidative activities of products of browning reaction prepared from glucosamine. The Japanese Journal of Nutrition and Dietetics 44:307-315. https://doi.org/10.5264/eiyogakuzashi.44.307

Paoletti F, Mocali A (1990) Determination of superoxide dismutase activity by purely chemical system based on NADPH oxidation. Oxygen radicals in biological systems Part B: Oxygen radicals and antioxidants methods in Enzymology:209-220. https://doi.org/10. 1016/0076-6879(90)86110-h

Parry RM, Chandan RC, Shahani KM (1965) A rapid and sensitive assay of muramidase. Exp Biol Med 119:384-386. https://doi.org/10. 3181/00379727-119-30188

Pearse AGE (1968) Histochemistry: theoretical and applied, 3rd edn. J and A Churchill Ltd., London, pp 13-102

Premanathan M, Karthikeyan K, Jeyasubramanian K, Manivannan G (2011) Selective toxicity of $\mathrm{ZnO}$ nanoparticles toward Grampositive bacteria and cancer cells by apoptosis through lipid peroxidation. Nanomedicine 7:184-192. https://doi.org/10.1016/j.nano. 2010.10.001

Quade MJ, Roth JA (1997) A rapid, direct assay to measure degranulation of bovine neutrophil primary granules. Vet Immunol Immunopathol 58:239-248. https://doi.org/10.1016/s0165-2427(97)00048-2

Ruas CBG, Dos Santos CC, De Araújo HSS, Espíndola ELG, Fernandes MN (2008) Oxidative stress biomarkers of exposure in the blood of cichlid species from a metal-contaminated river. Ecotoxicol Environ Saf 71:86-93

Saber TH (2011) Histological adaptation to thermal changes in gills of common carp fishes Cyprinus carpio. L Rafidain J Sci 22:46-55

Safawo T, Sandeep B, Pola S, Tadesse A (2018) Synthesis and characterization of zinc oxide nanoparticles using tuber extract of anchote (Coccinia abyssinica (Lam.) Cong.) for antimicrobial and antioxidant activity assessment. OpenNano 3:56-63. https://doi.org/10. 1016/j.onano.2018.08.001 
Semple SL, Kellendonk CJ, Al-Hussinee L, Macinnes JI, Lumsden JS, Dixon B (2018) Serum IgM, MH class II $\beta$ genotype and respiratory burst activity do not differ between rainbow trout families displaying resistance or susceptibility to the coldwater pathogen, Flavobacterium psychrophilum. Aquaculture 483:131-140. https:// doi.org/10.1016/j.aquaculture.2017.10.020

Shahzad K, Khan MN, Jabeen F, Kosour N, Sohail M, Khan MKA, Ahmad M (2017) Bioaccumulation of manufactured titanium dioxide (TiO2), copper oxide $(\mathrm{CuO})$ and zinc oxide $(\mathrm{ZnO})$ nanoparticles in soft tissues of tilapia (Oreochromis mossambicus). Punjab Univ J Zool 32:237-243

Shahzad K, Khan MN, Jabeen F, Kosour N, Chaudhry AS, Sohail M, Ahmad N (2018) Toxicity of zinc oxide nanoparticles ( $\mathrm{ZnO} N P s$ ) in tilapia (Oreochromis mossambicus): tissue accumulation, oxidative stress, histopathology and genotoxicity. Int J Environ Sci Technol 16:1973-1984. https://doi.org/10.1007/s13762-018-1807-7

Shobana C, Rangasamy B, Poopal RK, Renuka S, Ramesh M (2018) Green synthesis of silver nanoparticles using Piper nigrum: tissuespecific bioaccumulation, histopathology, and oxidative stress responses in Indian major carp Labeo rohita. Environ Sci Pollut Res $25: 11812-11832$

Singh NP, Mccoy MT, Tice RR, Schneider EL (1988) A simple technique for quantitation of low levels of DNA damage in individual cells. Exp Cell Res 175:184-191. https://doi.org/10.1016/00144827(88)90265-0

Singh RP, Shukla VK, Yadav RS, Sharma PK, Singh PK, Pandey AC (2011) Biological approach of zinc oxide nanoparticles formation and its characterization. Adv Mater Lett 2:313-317. https://doi.org/ 10.5185/amlett.indias.204

Subashkumar S, Selvanayagam M (2014) Zinc oxide (ZnO) nanoparticles induced histopathological changes in the liver of freshwater fish (Cyprinus carpio). Cibtech J Zool 3:74-77

Suganthi P, Murali M, Sadiq Bukhari A, Syed Mohamed HE, Basu H, Singhal RK (2015) Behavioural and histological variations in Oreochromis mossambicus after exposure to $\mathrm{ZnO}$ Nanoparticles. Int J Adv Res 1:524-531

Suganya G, Karthi S, Shivakumar MS (2014) Larvicidal potential of silver nanoparticles synthesized from Leucas aspera leaf extracts against dengue vector Aedes aegypti. Parasitol Res 113:16731679. https://doi.org/10.1007/s00436-014-3811-2

Sundrarajan M, Ambika S, Bharathi K (2015) Plant-extract mediated synthesis of $\mathrm{ZnO}$ nanoparticles using Pongamia pinnata and their activity against pathogenic bacteria. Adv Powder Technol 26:1294 1299. https://doi.org/10.1016/j.apt.2015.07.001

Swain P, Das R, Das A, Padhi SK, Das KC, Mishra SS (2018) Effects of dietary zinc oxide and selenium nanoparticles on growth performance, immune responses and enzyme activity in rohu, Labeo rohita (Hamilton). Aquac Nutr 25:486-494. https://doi.org/ 10.1111/anu. 12874

Torres M Aloísio, Testa CP, Gáspari C, Masutti MB, Panitz CMN, CuriPedrosa R, Almeida EAD, Mascio PD, Filho DW (2002) Oxidative stress in the mussel Mytella guyanensis from polluted mangroves on Santa Catarina Island, Brazil. Mar Pollut Bull 44:923-932. https:// doi.org/10.1016/s0025-326x(02)00142-x

Vale G, Mehennaoui K, Cambier S, Libralato G, Jomini S, Domingos RF (2016) Manufactured nanoparticles in the aquatic environmentbiochemical responses on freshwater organisms: a critical overview. Aquat Toxicol 170:162-174. https://doi.org/10.1016/j.aquatox. 2015.11.019

Venkatachalam P, Jayaraj M, Manikandan R, Geetha N, Rene ER, Sharma N, Sahi S (2016) Zinc oxide nanoparticles (ZnONPs) alleviate heavy metal-induced toxicity in Leucaena leucocephala seedlings: a physiochemical analysis. Plant Physiol Biochem 110:59-69. https://doi.org/10.1016/j.plaphy.2016.08.022

Venuti V, Cannavà C, Cristiano MC, Fresta M, Majolino D, Paolino D, Stancanelli R, Tommasini S, Ventura CA (2014) A characterization study of resveratrol/sulfobutyl ether- $\beta$-cyclodextrin inclusion complex and in vitro anticancer activity. Colloids Surf B: Biointerfaces 115:22-28. https://doi.org/10.1016/j.colsurfb.2013.11.025

Vimala K, Sundarraj S, Paulpandi M, Vengatesan S, Kannan S (2014) Green synthesized doxorubicin loaded zinc oxide nanoparticles regulates the Bax and Bcl-2 expression in breast and colon carcinoma. Process Biochem 49:160-172. https://doi.org/10.1016/j.procbio. 2013.10.007

Wang T, Long X, Liu Z, Cheng Y, Yan S (2015) Effect of copper nanoparticles and copper sulphate on oxidation stress, cell apoptosis and immune responses in the intestines of juvenile Epinephelus coioides. Fish Shellfish Immunol 44:674-682. https://doi.org/10.1016/j.fsi. 2015.03.030

Whyte SK (2007) The innate immune response of finfish - a review of current knowledge. Fish Shellfish Immunol 23:1127-1151. https:// doi.org/10.1016/j.fsi.2007.06.005

Zhang L, Jiang Y, Ding Y, Povey M, York D (2007) Investigation into the antibacterial behaviour of suspensions of $\mathrm{ZnO}$ nanoparticles (ZnO nanofluids). J Nanopart Res 9:479-489. https://doi.org/10. 1007/s11051-006-9150-1

Publisher's note Springer Nature remains neutral with regard to jurisdictional claims in published maps and institutional affiliations. 